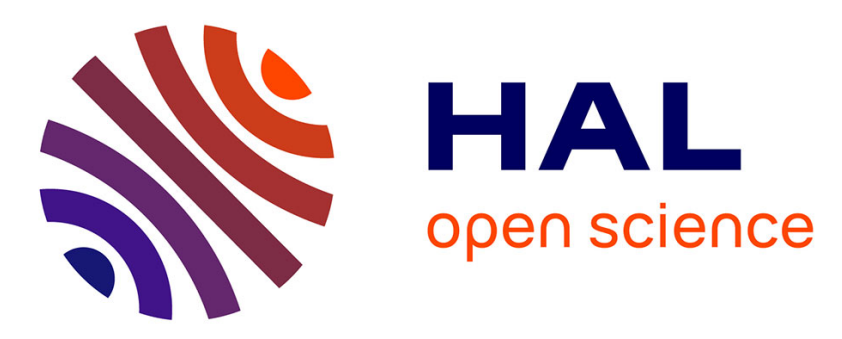

\title{
Synthesis, Crystal structure, Electrochemical, Theoretical Studies and Antioxidant Activities of New Schiff Base
}

\author{
Amira Abdelmadjid Madi, Djahida Haffar, Fatiha Benghanem, Samira \\ Ghedjati, Linda Toukal, Vincent Dorcet, Riadh Bourzami
}

\section{To cite this version:}

Amira Abdelmadjid Madi, Djahida Haffar, Fatiha Benghanem, Samira Ghedjati, Linda Toukal, et al.. Synthesis, Crystal structure, Electrochemical, Theoretical Studies and Antioxidant Activities of New Schiff Base. Journal of Molecular Structure, 2021, 1227, pp.129368. 10.1016/j.molstruc.2020.129368 . hal-03040879

\section{HAL Id: hal-03040879 \\ https://hal-univ-rennes1.archives-ouvertes.fr/hal-03040879}

Submitted on 15 Dec 2020

HAL is a multi-disciplinary open access archive for the deposit and dissemination of scientific research documents, whether they are published or not. The documents may come from teaching and research institutions in France or abroad, or from public or private research centers.
L'archive ouverte pluridisciplinaire HAL, est destinée au dépôt et à la diffusion de documents scientifiques de niveau recherche, publiés ou non, émanant des établissements d'enseignement et de recherche français ou étrangers, des laboratoires publics ou privés. 


\section{HIGHLIGHTS}

- Synthesis of new Schiff base ligand.

- Characterization of ligand by ${ }^{1} \mathrm{HNMR},{ }^{13} \mathrm{CNMR}, \mathrm{IR}, \mathrm{UV}-\mathrm{Vis}$.

- Determination of the ligand's crystal structure by X-ray diffraction method.

- Electrochemical studies.

- Antioxidant activity studies of synthesized compound.

- Theoretical studies using DFT calculations 


\section{Synthesis, Crystal structure, Electrochemical, Theoretical Studies and} Antioxidant Activities of New Schiff Base

Amira ABDELMADJID MADI ${ }^{\mathrm{a}}$, Djahida HAFFAR ${ }^{\mathrm{a}}$, Fatiha BENGHANEM $^{\mathrm{b}^{*}}$, Samira GHEDJATI $^{\mathrm{c}}$, , Linda TOUKAL ${ }^{\mathrm{a}}$, Vincent DORCET ${ }^{\mathrm{d}}$, Riadh BOURZAMI $^{\mathrm{e}}$

${ }^{a}$ Laboratory of Electrochemistry and Materials (LEM) Department of Engineering Process, Faculty of Technology, Ferhat Abbas University Setif-1, Setif 19000, Algeria.

${ }^{\mathrm{b}}$ Laboratory of Electrochemistry, Molecular Engineering and Redox Catalysis (LEIMCR)

Department of Engineering Process, Faculty of Technology, Ferhat Abbas University Setif-1, Setif 19000, Algeria.

${ }^{\mathrm{c}}$ Laboratory of Phytotherapy Applied to Chronic Diseases Faculty of Natural and Life sciences, University Ferhat Abbas Setif-1, Setif 19000, Algeria.

${ }^{\mathrm{d}}$ Univ Rennes, CNRS, ISCR (Institut des Sciences Chimiques de Rennes) - UMR 6226, 35000 Rennes, France.

${ }^{\mathrm{e}}$ Emerging Materials Reaserch Unit, Ferhat Abbas University Setif -1, Setif 19000, Algeria.

*Corresponding author. E-mail address:benghanem_f@yahoo.fr

\section{Abstract}

A novel Schiff base 2, 2'-((1E,1'E)-((4-methyl-1, 3-phenylene) bis (benzylidene)) bis (methylethylidene)) bis (4-methoxyphenol) (L) was the result of the reaction between 2, 4diaminotoluene and 2-hydroxy-5-methoxy benzaldehyde. The compound (L) was characterized using IR, UV-Vis, ${ }^{1} \mathrm{H}$, and ${ }^{13} \mathrm{C}$ NMR techniques. The structure of the ligand was determined by X-Ray Diffraction method (XRD). All experimental results were proved and explained theoretically exploiting DFT (Density Functional Theory) calculations. The electrochemical properties were studied through the cyclic voltammetry and the results were explained by the mean of the FMOs (Frontier Molecular Orbitals). The antioxidant activity of the synthesized Schiff base was evaluated by utilizing several tests as DPPH (1, 1-diphenyl-2picryl hydrazyl), ABTS (2, 2'-azino-bis(3-ethyl benzthiazoline-6-sulfonicacid), hydroxyl radical scavenging test, reducing power test, $\beta$-carotene bleaching test as chemical methods, and the superoxide radical scavenging as electrochemical method. The effective concentration $\left(\mathrm{EC}_{50}\right)$ showed that the compound has a good antioxidant activity, and the relationship 
between the structure-activity and the calculated electronic properties demonstrates that the compound has a good reactivity.

Keywords: Synthesis, Schiff base, DFT, cyclic voltammetry, effective concentration, antioxidant activity.

\section{Introduction}

Schiff bases result from the reaction between primary amine with an aldehyde or a keton under specific conditions, and they have iminic function $(\mathrm{C}=\mathrm{N})$. This name (Schiff bases) is relative to the person who discovered them (Hugo Schiff) [1]. Schiff bases are the most prevalent and commonly used organic compounds in many domains. They are used in medicine, and in biological activities as antioxidant, antimicrobial, antibacterial, antifungal, and anti-inflammatory [2-6].

In recent times, Schiff bases attract the researchers including biologists to its application as an antioxidant [7]. These compounds play an important role in the development of coordination chemistry. This is clearly explained by a number of publications showing the electrochemical properties of these compounds [8,9].

Many researches proved the highly effective of Schiff bases in scavenging free radicals. The harmful effects of the free radicals that cause potential biological damage are called "oxidative stress". The free radicals change the cell structure in the human body and cause damage and various diseases like cancer, autoimmune disease, neurological disorders, Alzheimer's disease, and diabetes disease [10-12].

A new series of Schiff bases of spiro-isatin was synthesized, and its ability to sweep the free radicals utilizing the antioxidant activities tests as DPPH (1, 1-diphenyl-2-picryl hydrazyl), ABTS (2, 2-azinobis-(3-ethylbenzothiazoline-6-sulfonic acid) and CUPRAC (the cupric reducing antioxidant capacity) was investigated and the results showed that the compounds exhibit higher ABTS cation radical scavenging ability than DPPH and CUPRAC activities. The structure-activity relationship proved that the high radical scavenging activities not only linked to the existence of the hydroxyl group, but also linked to the number and position of the group, for example in the DPPH radical scavenging the 2, 3-di-OH compound indicated a stronger antioxidant activity compared to 2, 5-di-OH compound, 2, 4, 6-tri-OH compound, and 3-OH compound. All the compounds containing one or two hydroxyl groups exhibit better antioxidant activities than the compounds containing methoxy group. The 
quantum chemical calculations show that the Highest Occupied Molecular orbital (HOMO) and the Lowest Unoccupied Molecular Orbital (LUMO) energies, electronegativity and chemical softness of the molecules are effective on the explanation of their antioxidant activities [13].

Another study about the derivatives of 4-methyl benzimidazole supports the last study, about the number and the position of the hydroxyl group [14]. In addition, the study shows that the phenyl ring which has hydroxyl and methoxy groups has a weaker antioxidant activity compared to phenyl ring with just hydroxyl group. And also the position of the hydroxyl and methoxy groups play a role. For example, a phenyl ring with 2-hydroxy, 4-methoxy shows a good antioxidant activity compared to the ring with 2-hydroxy-5-methoxy. The Schiff bases which have hydroxyl group adjacent to $\mathrm{N}$ atom also increase the radical scavenging efficiency (Radical-induced hemolysis of human erythrocytes) [15].

The aim of this study is to investigate the ability of new Schiff base 2, 2'-((1E,1'E)-((4methyl-1, 3-phenylene) bis (benzylidene)) bis (methylethylidene)) bis (4-methoxyphenol) on sweeping the free radicals using different methods as DDPH, ABTS, hydroxyl radical scavenging, reducing power test, $\beta$-carotene bleaching test, and the superoxide radical scavenging using the Cyclic Voltammetry (CV) method. The structure of the Schiff base was determined using ${ }^{1} \mathrm{H},{ }^{13} \mathrm{C}$ NMR, FT-IR (Fourier transform infrared), and UV-Vis. Its structural geometry was determined by X-ray crystallography. The theoretical study (DFT) was realized and the electrochemical properties were investigated using the cyclic voltammetry.

\section{Experimental Details}

\subsection{Materials and physical-chemical measurements}

All the chemical compounds and solvents were purchased from Merck, SigmaAldrich, or Fluka and were used without further purification.

The melting point of the ligand L was determined on a Kofler Bank 7779 apparatus. Perkin-Elmer 1000-FT-IR instrument was used to record FT-IR spectra. FT-IR spectrum was taken by using $\mathrm{KBr}$ pellet technique at the interval of $500-4000 \mathrm{~cm}^{-1}$ in the solid phase of the sample. The UV-Vis spectrum was recorded in DMF on a U-650 JASCO spectrophotometer. ${ }^{1} \mathrm{H}$ NMR, ${ }^{13} \mathrm{C}$ NMR spectra were recorded on Bruker spectrometer (working frequency 400 $\mathrm{MHz}$ and $100 \mathrm{MHz}$ ). 


\subsection{Synthesis of new Schiff base 2,2'-((1E,1'E)-((4-methyl-1,3-phenylene) bis (azanylylidene)) bis (methanylylidene)) bis (4-methoxyphenol) (L)}

We prepared the Schiff base L by mixing a methanolic solution $(15 \mathrm{ml})$ of 2,4diaminotoluene, (3 mmol, $0.3665 \mathrm{~g}$ ) with 2-hydroxy-5-methoxy benzaldehyde (6 mmol, $0.9129 \mathrm{~g}$ ) in the same volume of methanol (Scheme 1) according to the procedure described in the literature [16]. The mixture was then refluxed with stirring for two hours at $60{ }^{\circ} \mathrm{C}$. Finally, an orange precipitate was formed and was then cooled to room temperature, filtered, washed several times with methanol and diethylether, and dried in air. Recrystallization in a mixture of Methanol + Acetone (2/5) and dried at room temperature. The final product was recovered with yield: $85 \%$; m.p: $94{ }^{\circ} \mathrm{C} .{ }^{1} \mathrm{H}-\mathrm{NMR}$ (400 MHz; DMSO-d6, ppm): 12.47, 12.63 (2s, 2H, -OH); 8.97, $9.01(2 \mathrm{~s}, 2 \mathrm{H},-\mathrm{CH}=\mathrm{N}-)$; 6.91-7.42 (m, 9H, aromatic protons); 2.354 (s,

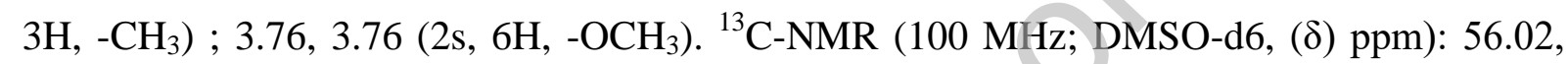
$56.05\left(-\mathrm{O}-\mathrm{CH}_{3}\right) ; 163.16,163.77(-\mathrm{CH}=\mathrm{N}-) ; 17.90\left(-\mathrm{CH}_{3}\right) ; 111.41$ to 155.03 (m, 11C, aromatic carbons). IR $\left(\mathrm{KBr}, \mathrm{cm}^{-1}\right)$ : $3327 v(\mathrm{OH}), 2932-3008 v(\mathrm{CH}), 1587 v(\mathrm{C}=\mathrm{N}), 1396 v(\mathrm{C}=\mathrm{C})$, $1274 v(\mathrm{C}-\mathrm{O}), 1112 \delta(\mathrm{O}-\mathrm{H}), 1040 v\left(\mathrm{OCH}_{3}\right) . \mathrm{UV}-\mathrm{V}$ is $(\lambda \max , \mathrm{nm}, \mathrm{DMF}$ as solvent): 276, 376.

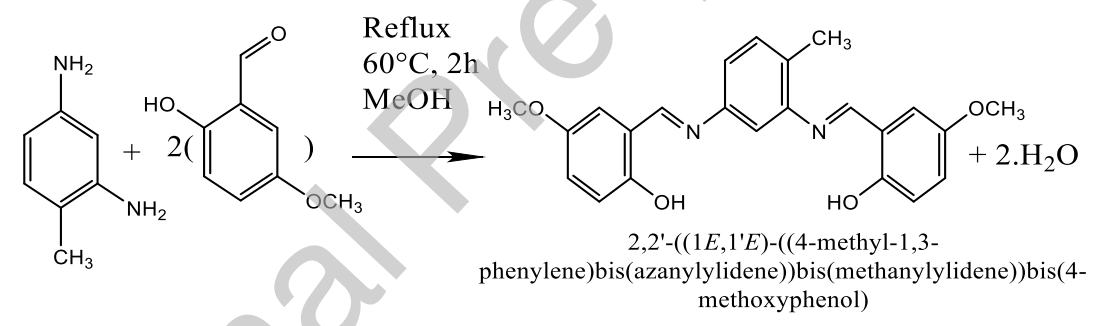

Scheme.1. Reaction scheme for the synthesis of Schiff base L.

\subsection{X-Ray diffraction analysis}

The diffraction data were collected on a Bruker D8 Venture photon diffractometer using graphite monochromated Mo Ka radiation $(\lambda=0.71073 \AA$ ). The structure was solved by direct methods using the SHELXL-2015 and SHELXL-2017 (Sheldrick, 2015 and Sheldrick, 2017) programs [17]. All of the non-hydrogen atoms were refined anisotropically and the hydrogen atoms were included in geometric positions but not refined.

\subsection{Quantum chemical calculations}

All the theoretical calculations and the geometry optimization were completed by using Gaussian 6.0 software, based on the Density Functional Theory (DFT), with Lee-YangParr correlation functional (B3LYP) and 6-31G (d, p) basis set $[18,19]$. The gas phase, which optimized, was used to compute theoretical vibrational frequencies of the $\mathrm{L}$ compound. 
For the comparison between the experimental vibrational frequencies and the theoretical vibrational frequencies, the scale factor $(0.9614)$ was used to scale the theoretical wave numbers [20]. The ${ }^{1} \mathrm{H}-\mathrm{NMR}$ and ${ }^{13} \mathrm{C}-\mathrm{NMR}$ chemical shifts were calculated by the Gaugeincluding atomic orbital (DFT-GIAO) method [21]. The quantum chemical parameters were calculated using the following equations [22].

$\begin{array}{ll}\text { Ionization Energy }(\mathrm{I}) & \mathrm{I}=-\mathrm{E}_{\mathrm{HOMO}} \\ \text { Electron Affinity }(\mathrm{A}) & \mathrm{A}=-\mathrm{E}_{\mathrm{LUMO}} \\ \text { Chemical Hardness }(\eta) & \eta=\left(\mathrm{E}_{\mathrm{LUMO}}-\mathrm{E}_{\mathrm{HOMO}}\right) / 2 \\ \text { Chemical Softness }(\sigma) & \sigma=1 / \eta \\ \text { Electrophilicity Index }(\omega) & \omega=\mu^{2} / 2 \eta \\ \text { Electronegativity }(\chi) & \chi=(\mathrm{I}+\mathrm{A}) / 2 \\ \text { Chemical Potential }(\mu) & \mu=-\chi \\ \Delta \mathrm{E}_{\mathrm{GAP}}(\mathrm{eV}) & \Delta \mathrm{E}_{\mathrm{GAP}}=\mathrm{E}_{\mathrm{LUMO}}-\mathrm{E}_{\mathrm{HOMO}}\end{array}$

\subsection{Electrochemical method}

Electrochemical measurements were carried out using a potentiostat (Radiometer Analytical PGZ 301) piloted by Voltamaster 4 software and connected to a computer.

The working electrode was made of glassy carbon $\left(7 \mathrm{~mm}^{2}\right.$ areas $)$ and the auxiliary electrode was a platinum plate $\left(50 \mathrm{~mm}^{2}\right.$ areas). A saturated calomel electrode (SCE) was used as the reference electrode and the measurements were carried out at room temperature. DMF was used as a solvent and the strength of the ions was maintained at $0.1 \mathrm{M}$ with $\mathrm{LiClO}_{4}$ as a supporting electrolyte. The voltammograms were recorded in a potential range from +1600 to $-2000 \mathrm{mV} / \mathrm{SCE}$, under nitrogen atmosphere at a scan rate of $50 \mathrm{mV} / \mathrm{s}$. Ferrocene / ferrocenium $\left(\mathrm{Fc} / \mathrm{Fc}^{+}\right)$was used as an international standard.

Under the same experimental conditions, the trapping of superoxide radical was studied with slight modifications [23]. The electrolytic solution (DMF, $\mathrm{LiClO}_{4} 0.1 \mathrm{M}$ ) was saturated by $\mathrm{O}_{2}$ during $15 \mathrm{~min}$ at a scanning speed of $100 \mathrm{mV} / \mathrm{s}$ with a sweeping potential range from 800 to $-1500 \mathrm{mV} / \mathrm{SCE}$. Then, the tested sample and the standard were added with progressively increasing concentration. The percentage of superoxide radical scavenging was determined using the formula:

$$
\operatorname{RSAO}_{2}{ }^{--}(\%)=\left(\left(\mathrm{i}^{\circ} \mathrm{pa}^{-} \mathrm{i}_{\mathrm{p}}\right) / \mathrm{i}_{\mathrm{pa}}^{\circ}\right) \times 100
$$


Where $i_{p a}^{\circ}$ and $i_{p a}$ are the anodic peaks current of oxidation without and with the tested samples.

The binding constant $\left(\mathrm{K}_{\mathrm{b}}\right)$ and Gibbs free energy $\left(\Delta \mathrm{G}^{\circ}\right)$ were calculated using the following equations [24]:

$$
\begin{aligned}
& \log \left(1 / \mathrm{C}_{\text {test }}\right)=\log \mathrm{K}_{\mathrm{b}}+\log \left(\mathrm{i}_{\mathrm{pa}} /\left(\mathrm{i}_{\mathrm{pa}}^{\circ}-\mathrm{i}_{\mathrm{pa}}\right)\right) \\
& \Delta \mathrm{G}^{\circ}=-\mathrm{RT} \ln \left(\mathrm{C}_{\mathrm{S}} \times \mathrm{K}_{\mathrm{b}}\right)
\end{aligned}
$$

where $\mathrm{T}$ is the absolute temperature $(\mathrm{K})$

$\mathrm{R}$ is the gas constant $\left(8.314 \mathrm{~J} \cdot \mathrm{K}^{-1} \cdot \mathrm{mol}^{-1}\right)$

$\mathrm{C}_{\mathrm{s}}$ is the concentration of the solvent $\mathrm{DMF}=12.78 \mathrm{M}$

\subsection{Antioxidant activities}

\subsubsection{Radical Scavenging Activity DPPH}

The DPPH (1, 1-diphenyl-2-picryl hydrazyl) test is one of the most familiar and relatively fast methods, used to measure the ability of antioxidants to sweep free radicals. In this case, the radical scavenging activity of the tested sample (L) and Butylated hydroxytoluene (BHT) standard was evaluated according to the reported method, with large modifications [25]. We added $500 \mu 1$ of DPPH solution to $250 \mu 1$ of the tested sample (L) and BHT solutions at different concentrations in absolute ethanol. Then, incubated for $30 \mathrm{~min}$ at room temperature. The absorbance values were measured at $517 \mathrm{~nm}$.

The effective concentration $\left(\mathrm{EC}_{50}\right)$ value of the tested sample $(\mathrm{L})$ and $\mathrm{BHT}$, is the concentration necessary of the tested sample to inhibit $50 \%$ of the free radical. It was calculated using the linear regression analysis. The percent DPPH scavenging effect was calculated using the following equation [26]:

$$
\% \text { inhibition }=\left(\left(\mathrm{A}_{0}-\mathrm{A}_{1}\right) / \mathrm{A}_{0}\right) \times 100
$$

Where $\mathrm{A}_{0}$ is the absorbance of the control sample (DPPH solution) and $\mathrm{A}_{1}$ is the absorbance of the tested samples (L) (DPPH solution with tested sample or standard).

\subsubsection{Radical Scavenging Activity ABTS}

The ABTS method is based on the ability of hydrogen or electron-donating antioxidants to decolorize the performed radical monocation of 2, 2'-azino-bis(3ethylbenzthiazoline-6-sulfonicacid) generated from the oxidation of ABTS with potassium persulfate [27]. The ABTS free radical scavenging activity of the tested sample (L) and BHT standard was investigated by using the method described in the literature [28]. $7 \mathrm{mM}$ ABTS was dissolved in water with $2.45 \mathrm{mM}$ potassium persulfate. The mixture was stored in the 
dark for 16 hours at room temperature before use. The ABTS solution was diluted with methanol to an absorbance of $0.700 \pm 0.002$. $50 \mu \mathrm{l}$ of tested sample solution at different concentrations were added to $1 \mathrm{ml}$ of ABTS solution and incubated for $15 \mathrm{~min}$ at room temperature. The absorbance was recorded at $743 \mathrm{~nm}$. The $\mathrm{EC}_{50}$ and the percent ABTS scavenging effect results were calculated like the same method of DPPH radical scavenging activity.

\subsubsection{Hydroxyl radical Scavenging Activity $(\mathrm{OH})$}

The hydroxyl radical $\left(\mathrm{OH}^{*}\right)$ scavenging activity was measured according to the literature method [29]. $100 \mu \mathrm{l}$ of the tested sample (L) or standard (ascorbic acid) including different concentrations was added to the reaction mixture of $500 \mu 1 \mathrm{FeSO}_{4}, 350 \mu 1 \mathrm{H}_{2} \mathrm{O}_{2}, 150$ $\mu \mathrm{l}$ salicylic acid. Then the mixture was vortexed and incubated for $60 \mathrm{~min}$ at $37{ }^{\circ} \mathrm{C}$. The absorbance of the mixture was measured at $562 \mathrm{~nm}$. The inhibition percentage was calculated using the formula:

$$
\mathrm{OH}^{\bullet} \text { scavenging }(\%)=\left(\left(\mathrm{A}_{\mathrm{c}}-\mathrm{A}_{\mathrm{s}}\right) / \mathrm{A}_{\mathrm{c}}\right) \times 100
$$

Where $A_{c}$ is the absorbance of the control sample (reaction mixture with water instead of samples) and $\mathrm{A}_{\mathrm{s}}$ is the absorbance of the tested samples (reaction mixture with standard or tested sample (L)). The $\mathrm{EC}_{50}$ was calculated using linear regression analysis.

\subsubsection{Reducing power}

The reducing power test is based on the ability of the tested compounds to reduce the ferric iron $\left(\mathrm{Fe}^{3+}\right)$ to the ferrous iron $\left(\mathrm{Fe}^{2+}\right)$ in the presence of the solvent fraction. The reducing power was evaluated according to the method described in the literature [30] as following: $100 \mu \mathrm{l}$ of the tested sample (L) at different concentrations was mixed with $100 \mu \mathrm{l}$ of phosphate buffer $(\mathrm{pH}=6.6)$ and potassium ferricyanide $\left[\mathrm{K}_{3} \mathrm{Fe}(\mathrm{CN})_{6}\right]$. The mixture was incubated for $20 \mathrm{~min}$ at $50{ }^{\circ} \mathrm{C}$, and then $250 \mu \mathrm{l}$ of trichloroacetic acid was added to the mixture and centrifuged for $10 \mathrm{~min}$ at $3000 \mathrm{rmp}$. after that, $250 \mu \mathrm{l}$ of the mixture was added to $250 \mu 1$ of water and $500 \mu \mathrm{l}$ of ferric chloride $\left(\mathrm{FeCl}_{3}\right)$. The absorbance was measured at 700 $\mathrm{nm}$. The BHT was used as a standard. The $\mathrm{EC}_{50}$ was calculated from the absorbance graph against sample concentration.

\subsection{5. $\beta$-carotene bleaching test ( $\beta$-CBTS)}

The antioxidant capacity of the tested samples was determined by measuring the inhibition of the oxidative degradation of $\beta$-carotene by the products of linoleic acid [31]. The 
$\beta$-CBTS was investigated following the literature [32]. A solution of $\beta$-carotene $(0.5 \mathrm{mg})$ in 1 $\mathrm{ml}$ of chloroform was added to $25 \mu \mathrm{l}$ of linoleic acid and $200 \mathrm{mg}$ of tween 40 . In the rotary evaporator, the chloroform was evaporated at $40{ }^{\circ} \mathrm{C}$, then $100 \mathrm{ml}$ of distilled water saturated with oxygen was added to the mixture. after that, $2.5 \mathrm{ml}$ from the mixture was added to $35 \mathrm{ml}$ of the tested sample $(2 \mathrm{mg} / \mathrm{ml})$ prepared in methanolic solution. The same method was used for the positive standard BHT and the negative standards (water, ethanol). The absorbances were read at a different time $(0,2,4,6$ and $24 \mathrm{~h})$ at $490 \mathrm{~nm}$. The relative antioxidant activities were calculated as the following formula:

$$
\text { AA }(\%)=(\text { absorbance of sample / absorbance of BHT }) \times 100
$$

All the experiments were carried out in triplicate. The results were reported by calculating the mean \pm standard deviation of three experiments.

\section{Results and discussion}

\subsection{XRD analysis}

The structure of the ligand was determined using X-ray diffraction analysis. It proved that the molecular formula of the ligand $\mathrm{L}$ is $\mathrm{C}_{23} \mathrm{H}_{22} \mathrm{~N}_{2} \mathrm{O}_{4}$, the bond lengths $\mathrm{C} 8-\mathrm{N} 1$ and C16$\mathrm{N} 2$ are 1.2861 (16) $\AA$, 1.2819 (16) Á respectively, these values correspond to $\mathrm{C}=\mathrm{N}$ double bond lengths and the bonds C9-N1 and C13-N2 have the values 1.4208 (15) $\AA$ and 1.4141 (15) respectively, they are compatible with the single bond C-N [33-37], these bonds confirm the formation of the Schiff base L. The results of DFT calculations are in good agreement with those obtained from experimental data, for example the calculated N2-C13 and N2-C16 bond lengths differ from the experimental values by $0.0051,0.0107$ respectively. In addition, the C5-O2 and C18-O3 bond length are respectively 1.3543 (15) and 1.3567 (15) Á, they are perfectly comparable to the corresponding length 1.3566 (17) Á of N'-[(Z)-(2-hydroxy-4methoxyphenyl) methylidene] pyridine-3-carbohydrazide compound [38].

The crystal data, data collection, and structure refinement parameters are shown in Table 1 and some selected characteristic bond lengths and angles measurements estimated experimentally and theoretically are summarized in Table 2, the crystallographic data for the structure reported in this paper has been deposited in the Cambridge Crystallographic Data Center (CCDC), the deposition number is 2009273.

The asymmetric unit is shown in Figure 1a, it presents one molecule of the ligand L. Otherwise, the molecule is distorted from the planar form (Figure 1b), the angle 
measurements between the carrier planes of cycles are $10.55^{\circ}$ and $23.83^{\circ}$, in addition, the $\mathrm{C}$ $\mathrm{C}$ and $\mathrm{C}=\mathrm{C}$ bond distances are correlated with the aromatic rings and all angles in the aromatic phenyl rings are in the normal ranges and around $120^{\circ}$, showing $\mathrm{sp}^{2}$ hybridization of all $\mathrm{C}$ atoms.

Table.1. Crystal data, data collection and structure refinement parameters for the ligand L.

\begin{tabular}{|c|c|}
\hline Molecular formula moiety & $\mathrm{C}_{23} \mathrm{H}_{22} \mathrm{~N}_{2} \mathrm{O}_{4}$ \\
\hline Molecular weight (g/mol) & 390.42 \\
\hline Temperature (K) & $150(2)$ \\
\hline Radiation $\lambda, \operatorname{MoK} \alpha$ & $0.710730 \AA$ \\
\hline Crystal system & Monoclinic \\
\hline Space group & $\mathrm{P} 21 / \mathrm{c}$ \\
\hline $\mathrm{a} / \AA$ & $15.2573(7)$ \\
\hline $\mathrm{b} / \AA$ & $3.8970(2)$ \\
\hline $\mathrm{c} / \AA$ & $33.0536(14)$ \\
\hline$\beta\left(^{\circ}\right)$ & $91.800(2)$ \\
\hline Volume $/ \AA^{3}$ & $1964.32(16)$ \\
\hline $\mathrm{Z}$ & 4 \\
\hline Crystal dimension & $0.6 * 0.2 * 0.14$ \\
\hline Crystal habit/color & Orange \\
\hline$D_{\text {calc }}\left(\right.$ g.cm $\left.{ }^{-3}\right)$ & 1.320 \\
\hline Abs. coefficient $\left(\mathrm{mm}^{-1}\right)$ & 0.084 \\
\hline $\mathrm{F}(000)$ & 842 \\
\hline Reflections collected/unique & $4415 / 3707$ \\
\hline Range/indices $(h, k, 1)$ & $-19,19 ;-5,4 ;-42,42$ \\
\hline Teta $_{\text {limit }}$ & $2.6713 ; 27.5654$ \\
\hline No. of observed data $\mathrm{I}>2 \sigma(\mathrm{I})$ & 2678 \\
\hline No. of variables & 267 \\
\hline Goodness of fit on $\mathrm{F}^{2}$ & 1.032 \\
\hline Max. peak ato hole $\left(\mathrm{e}^{-3}\right)$ & 0.235 and -0.231 \\
\hline $\mathrm{R}_{1}, \mathrm{wR}_{2}[\mathrm{I} \geq 2 \operatorname{sigma}(\mathrm{I})]$ & $0.0493,0.1089$ \\
\hline $\mathrm{R}_{1}, w \mathrm{R}_{2}$ (all data) & $0.0397,0.1028$ \\
\hline
\end{tabular}

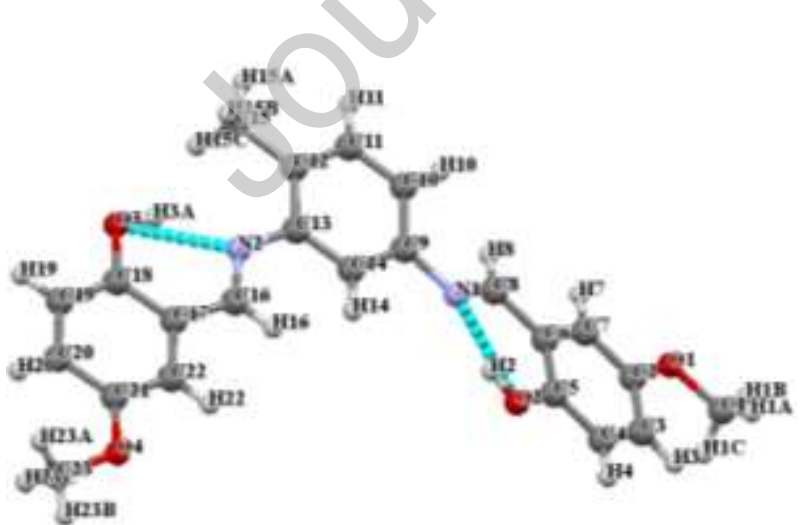

(a)

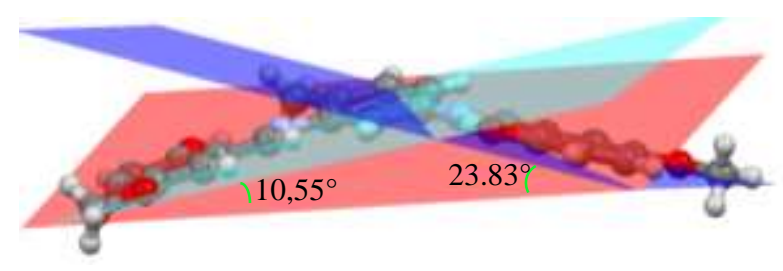

(b)

Figure.1. (a) Asymmetric unit of ligand provided with intramolecular hydrogen bonds (b) distortion of the molecular strucutre. 
Table. 2. Experimental and theoretical selected bond lengths $(\AA)$ and angles measurements $\left(^{\circ}\right)$ of the ligand $\mathrm{L}$.

\begin{tabular}{lcl|lcc}
\hline \multicolumn{3}{c|}{ Bond lengths $(\AA)$} & \multicolumn{3}{c}{ Bond angles $\left(^{\circ}\right)$} \\
\hline C2-O1 & Exp. & Cal. & & Exp. & Cal. \\
C1-O1 & $1.3789(14)$ & 1.3712 & O2-C5-C6 & $121.58(11)$ & 122.21 \\
C9-N1 & $1.4268(15)$ & 1.4168 & O3-C18-C17 & $122.03(11)$ & 122.17 \\
C8-N1 & $1.4208(15)$ & 1.4081 & C21-O4-C23 & $116.34(10)$ & 118.07 \\
C13-N2 & $1.2861(16)$ & 1.2927 & N1-C8-C6 & $121.77(11)$ & 122.17 \\
C16-N2 & $1.4141(15)$ & 1.4090 & N2-C16-C17 & $120.89(11)$ & 122.31 \\
C5-O2 & $1.2819(16)$ & 1.2926 & C16-N2-C13 & $123.51(10)$ & 121.01 \\
C18-O3 & $1.3543(15)$ & 1.3447 & C8-N1-C9 & $120.17(11)$ & 121.21 \\
& $1.3567(15)$ & 1.3451 & C9-C14-C13 & $121.05(11)$ & 121.11 \\
& & & C13-C12-C15 & $120.93(11)$ & 120.94 \\
\hline
\end{tabular}

The unit cell is shown in the Figure 2, its geometrical parameters are grouped in the Table 2. The crystal is monoclinic with $\mathrm{P} 21 / \mathrm{c}$ space group and the cell parameters are $\mathrm{a}=$ 15.2573(7) $\AA, b=3.8970(2) \AA, c=33.0536$ (14) $\AA$ and $\beta=91.800(2)^{\circ}$. The cell contains four asymmetric units $(Z=4)$, the unit cell is characterized by (x y z) identity, an inversion center at the point $\left(\begin{array}{lll}0 & 0 & 0\end{array}\right)$, a glide plane perpendicular to direction $\left[\begin{array}{lll}0 & 1 & 0\end{array}\right]$ with glide component $\left[\begin{array}{lll}0 & 0\end{array}\right.$ $1 / 2]$ and finally 2 -fold screw axis with the direction $\left[\begin{array}{lll}0 & 1 & 0\end{array}\right]$ at the points $\left(\begin{array}{lll}0 & \text { y } 1 / 4\end{array}\right)$ with screw component $\left[0 \frac{1}{2} 0\right]$.

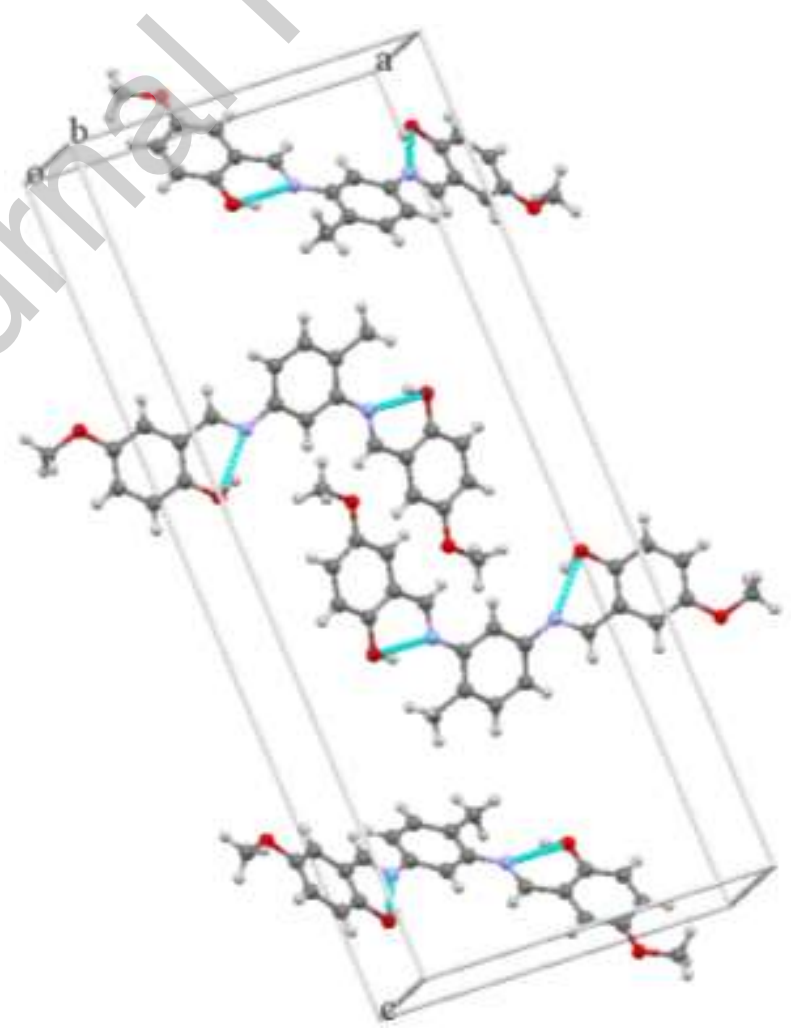

Figure.2. Unit cell of L, provided with intramolecular hydrogen bonds. 


\section{Hydrogen bonds and 3D network}

The 3D network is characterized by two intramolecular hydrogen bonds and two intermolecular hydrogen bonds, their characteristic geometrical parameters and symmetry code are summarized in Table 3. The intramolecular hydrogen bonds of the type $\mathrm{O}-\mathrm{H} \cdots \mathrm{N}$ are responsible on the distortion of the molecule, and the intermolecular hydrogen bonds of the type $\mathrm{O}-\mathrm{H} \cdots \mathrm{C}$ join the molecules into dimers (Figure 3 left), these dimers form a $\pi$ stacking along the b-axis, with characteristic distance about $3.918 \AA$ (Figure 3 right). The stackings are filed through the intermolecular hydrogen bonds $\mathrm{C}(8)-\mathrm{H} \cdots \mathrm{O}$ (1) molecular layer by molecular layer, these layers are inclined alternatively left and right by an angle of 23 ${ }^{\circ}$ from the c-axe, forming a complex 3D network.

Table.3. Hydrogen-bond geometry $\left(\AA{ }^{\circ}\right)$.

\begin{tabular}{ccccc}
\hline $\mathrm{D}-\mathrm{H} \cdots \mathrm{A}$ & $\mathrm{D}-\mathrm{H}$ & $\mathrm{H} \cdots \mathrm{A}$ & $\mathrm{D} \cdots \mathrm{A}$ & $\mathrm{D}-\mathrm{H} \cdots \mathrm{A}$ \\
\hline $\mathrm{O}(3)-\mathrm{H} \cdots \mathrm{N}(2)^{i}$ & 0.84 & 1.857 & 2.598 & 146.29 \\
$\mathrm{O}(2)-\mathrm{H} \cdots \mathrm{N}(1)^{i}$ & 0.84 & 1.871 & 2.616 & 146.97 \\
$\mathrm{O}(2)-\mathrm{H} \cdots \mathrm{C}(23)^{i i}$ & 0.84 & 3.046 & 3.177 & 91.20 \\
$\mathrm{C}(8)-\mathrm{H} \cdots \mathrm{O}(1)^{i i i}$ & 0.95 & 2.650 & 3.582 & 168.00 \\
\hline
\end{tabular}

${ }^{i}$ Symmetry code: (i) x,y,z (ii) 1-x, 2-y, 1-z (iii) -x+2, y-1/2, -z+3/2.

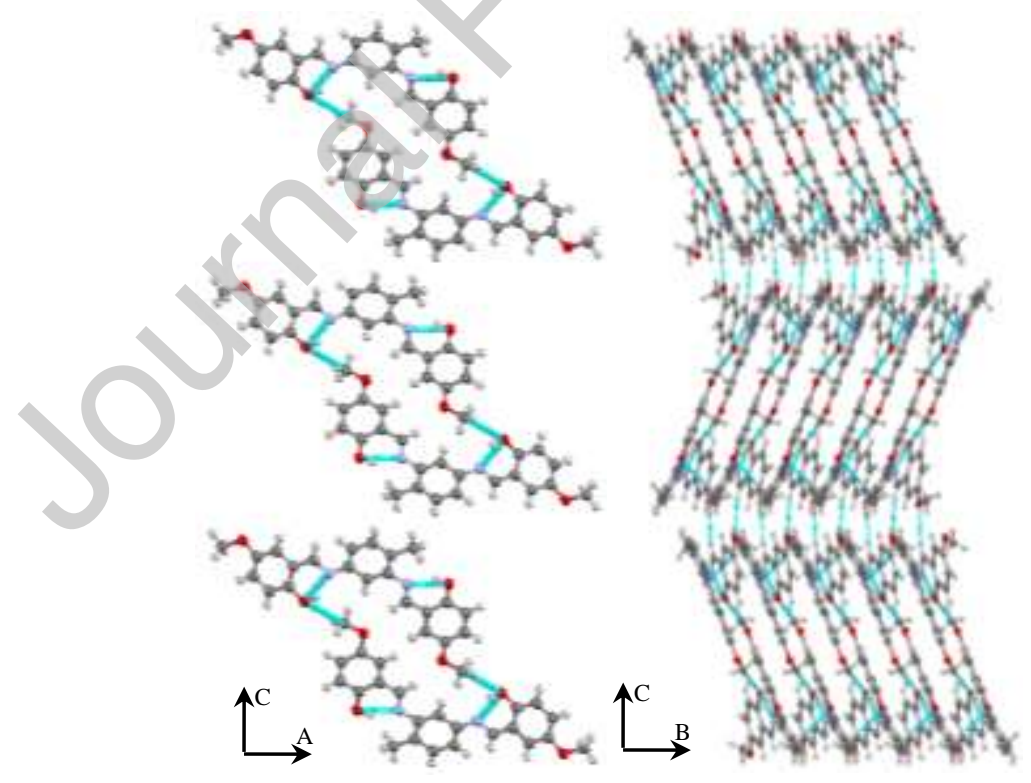

Figure.3. 3D network, left (COA) view and right (COB) view. 


\subsection{Spectroscopic studies}

\subsection{1. ${ }^{1} \mathrm{H}-\mathrm{NMR}$ and ${ }^{13} \mathrm{C}-\mathrm{NMR}$ analysis}

The ${ }^{1} \mathrm{H}-\mathrm{NMR}$ spectrum of the ligand $\mathrm{L}$ in $\mathrm{DMSO}_{\mathrm{d} 6}$ (Figure 4) shows the phenolic $\mathrm{OH}$ groups in the offset region at 12.47, 12.63 (singlets) and the azomethine protons at 8.97, 9.01 (singlets) [39-41]. The aromatic protons of the ligand L are observed as multiplets in the region between 6.91-7.42 (multiplets) [41]. An additional peak at 2.35 is attributed to $-\mathrm{CH}_{3}$ protons [40]. The signals relating to methoxy groups are observed at 3.76, 3.76 [39].

The ${ }^{13} \mathrm{C}-\mathrm{NMR}$ spectrum is shown in Figure 4. For the compound $\mathrm{L}$ two peaks appearing at 163.16 and $163.77 \mathrm{ppm}$ are attributed to imine carbon atoms (C10, C11) [42]. The aromatic carbons of $\mathrm{L}$ are observed between 111.41 to $155.04 \mathrm{ppm}$, the $\mathrm{C} 15, \mathrm{C} 18, \mathrm{C} 19$, $\mathrm{C} 22$ show more downfield due to the presence of electronegative groups $(\underline{\mathrm{C}}-\mathrm{OH}$ and $\underline{\mathrm{C}}-$ $\mathrm{OCH}_{3}$ ), are observed at 152.37 to $155.04 \mathrm{ppm}$ [43]. The $\mathrm{C} 27, \mathrm{C} 29$ of the methoxy groups $\left(\mathrm{OCH}_{3}\right)$ are detected at 56.02, $56.05 \mathrm{ppm}[33,42]$. On the other hand, the C7 of the methyl group $\left(\underline{\mathrm{CH}}_{3}\right)$ is detected at $17.91 \mathrm{ppm}$ [44]. The NMR data are collacted in Table 4.

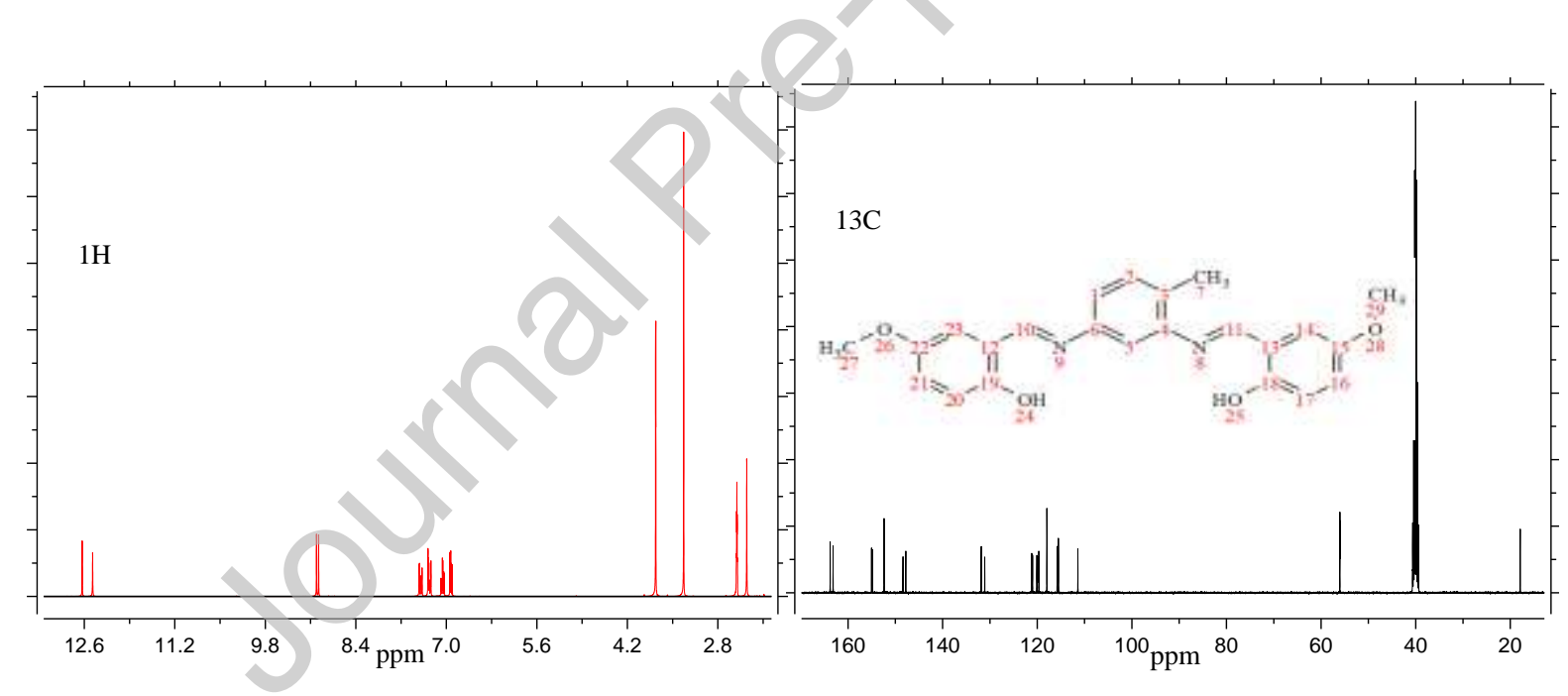

Figure.4. ${ }^{1} \mathrm{H}-\mathrm{NMR}$ and ${ }^{13} \mathrm{C}-\mathrm{NMR}$ spectra of the ligand L.

\subsubsection{FT-IR analysis}

The IR spectrum of the synthesized Schiff base L was carried out in the range 500$4000 \mathrm{~cm}^{-1}$ (Figure 5). The positions of the significant IR bands of $\mathrm{L}$ are summarized in Table 4. The IR spectrum of $L$ shows a strong band at $1587 \mathrm{~cm}^{-1}$ is assigned to $v(C=N)$ of the azomethine [45]. The band at $1396 \mathrm{~cm}^{-1}$ is assigned to $\mathrm{C}=\mathrm{C}$ stretching vibrations of the aromatic rings $[46,47]$. The band observed at $1274 \mathrm{~cm}^{-1}$ is due to $v(\mathrm{C}-\mathrm{O})$ [48]. 
Moreover $\left(-\mathrm{OCH}_{3}\right)$ stretching vibrations are observed around $1040 \mathrm{~cm}^{-1}$ [49]. Furthermore, stretching mode appeared at $3327 \mathrm{~cm}^{-1}$ is related to $(\mathrm{O}-\mathrm{H})$ of the phenolic group band [40, 44]. The absorption peaks in the region $2932-3008 \mathrm{~cm}^{-1}$ are attributed to asymmetric and symmetric stretching of $-\mathrm{CH}_{3}[39,41]$ and the band observed at $1112 \mathrm{~cm}^{-1}$ is attributed to the deformation of the phenolic group $(\delta(\mathrm{O}-\mathrm{H}))$ [48]. The observation of these bands confirms the formation of the new Schiff base L.

${ }^{1} \mathrm{H}-\mathrm{NMR},{ }^{13} \mathrm{C}-\mathrm{NMR}$, and IR spectra were compared and explained through theoretical DFTcalculations (Table 4). The spectroscopic analysis IR and NMR confirm a good consistency and are in good agreement with the DFT results.

The difference between theoretical and experimental IR shifts can be assigned to acidic character of phenolic protons and probably to the fact that the theoretical calculations were carried out in the gas phase for a single molecule. For this reason, intermolecular interactions are excluded thus hydrogen bonded $-\mathrm{OH}$ stretching mode deviate from experimental data.

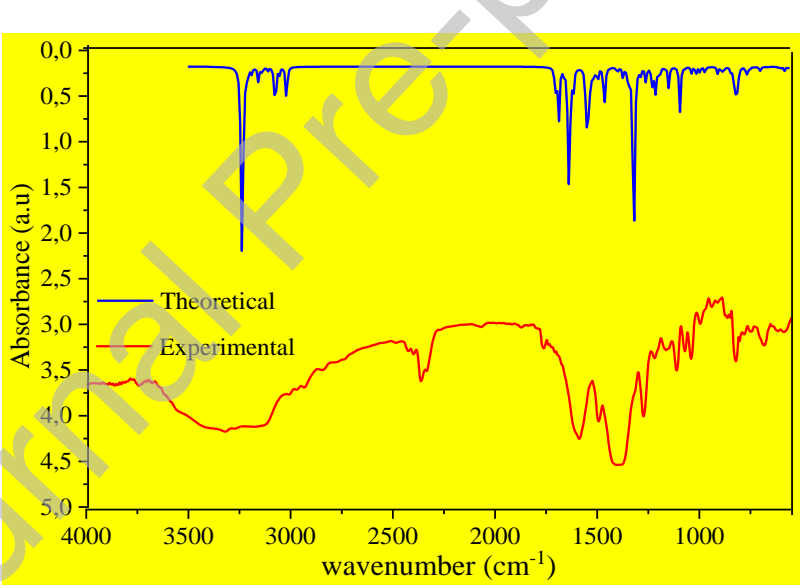

Figure.5. IR spectrum of compound L. 
Table.4. Experimental and calculated IR and ${ }^{1} \mathrm{H}-\mathrm{NMR}$ and ${ }^{13} \mathrm{C}-\mathrm{NMR}$ results.

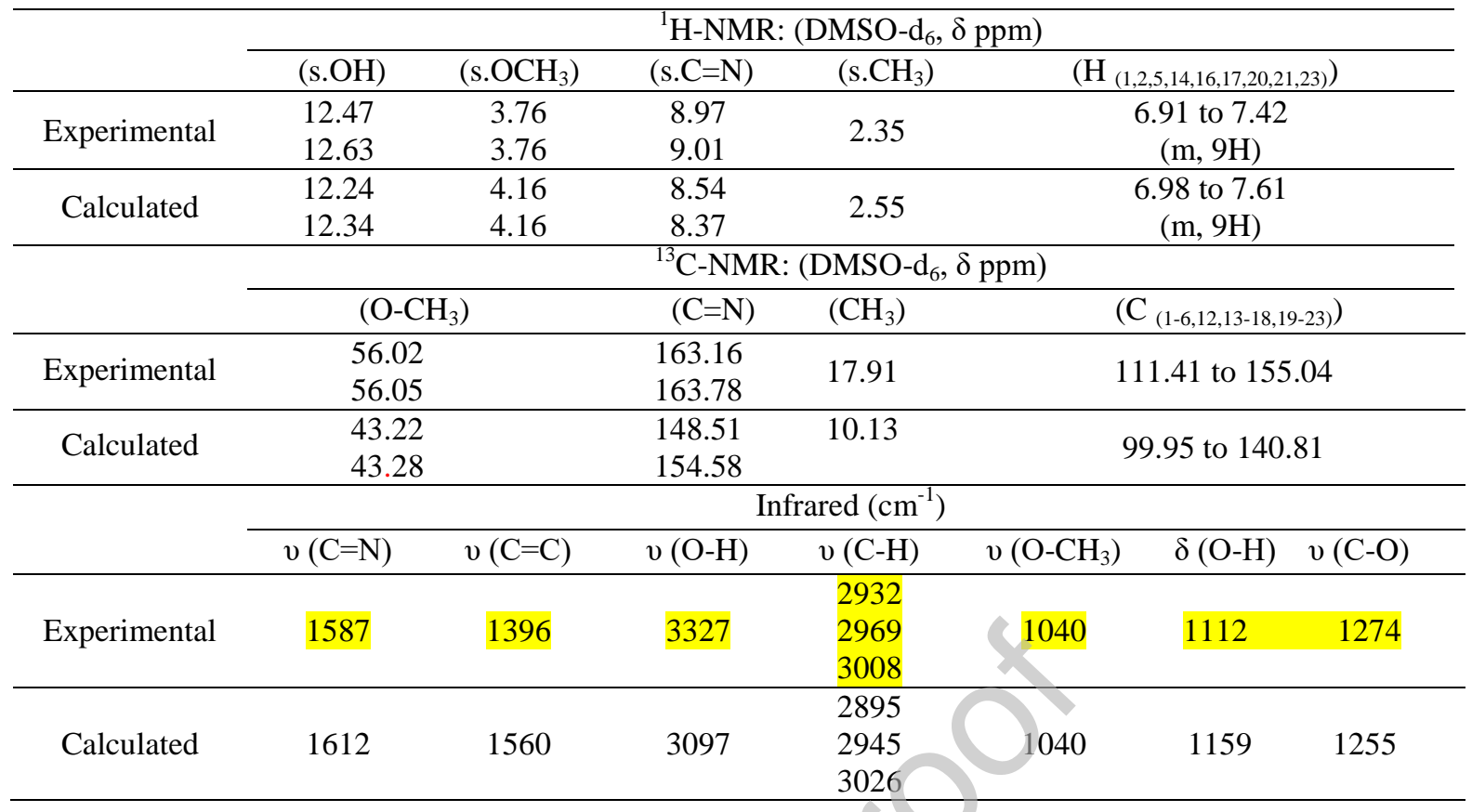

\subsubsection{UV-vis analysis}

The electronic spectral data of the synthesized compound was recorded in DMF solution at room temperature in the range of 250-850 $\mathrm{nm}$ (Figure 6) and it shows two bands in the UV region. The first band at $276 \mathrm{~nm}$ is assigned to the $\pi \rightarrow \pi^{*}$ transitions of the aromatic rings [50] and the second at $376 \mathrm{~nm}$ corresponding to the $\mathrm{n} \rightarrow \pi^{*}$ transition within the azomethine group [37, 43], over $450 \mathrm{~nm}$ the compound is transparent.

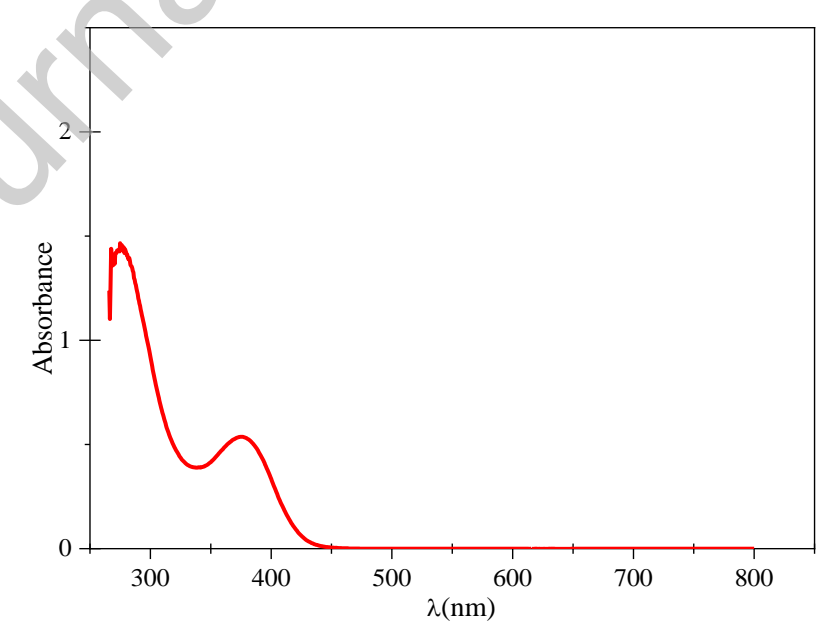

Figure.6. UV-Vis spectrum of the compound L. 


\subsection{Frontier Molecular Orbitals FMOs}

The Highest Occupied Molecular and the Lowest Unoccupied Molecular Orbitals (HOMO-LUMO) are terms more closely to the electron transfer concept such as electrons donor or acceptor. Through it, we can explain the nature of the chemical reactivity of molecules; the gap energy $\Delta \mathrm{E}_{\mathrm{GAP}}$ is defined by the absolute energy difference between HOMO and LUMO energies. So, the smaller gap energy reflects the high reactivity of the molecules. Moreover, hardness/softness and chemical potential are other parameters that can be calculated through FMOs energies, the soft molecule has a small energy of excitation compared to the hard molecule which needs high energy of excitation $[51,52]$.

It can be seen from the 3D plots (Figure 7) that the HOMO covers the molecule except the $\mathrm{CH}_{3}$ group, for the HOMO-1 some parts of the aromatic ring are not covered and the HOMO-2 is not uniform at the $-\mathrm{OCH}_{3}$ group and $-\mathrm{OH}$ group. The LUMO and LUMO+1 are spread over the molecule excluding the $\mathrm{OCH}_{3}$ and $\mathrm{CH}_{3}$ groups, for the $\mathrm{LUMO}+2$, it covers the right part of the molecule.

The relationship between the structure of the ligand $\mathrm{L}$ and its activity can be explained through the $\mathrm{HOMO} / \mathrm{LUMO}$ energies which display the first oxidation/reduction with $\Delta \mathrm{E}_{\mathrm{GAP} 1}$ equal to $3.56 \mathrm{eV}$ and confirm that the effective antioxidant activity of the ligand $\mathrm{L}$ is due to the phenolic group which donates an electron or an hydrogen atom and demonstrates that the ligand $\mathrm{L}$ has a good reactivity.

Some other physico-chemical parameters characteristic of the compound L are summarized in table 5. 


\section{$\Delta \mathrm{E}_{\mathrm{GAP} 1}=3.56 \mathrm{eV}$}
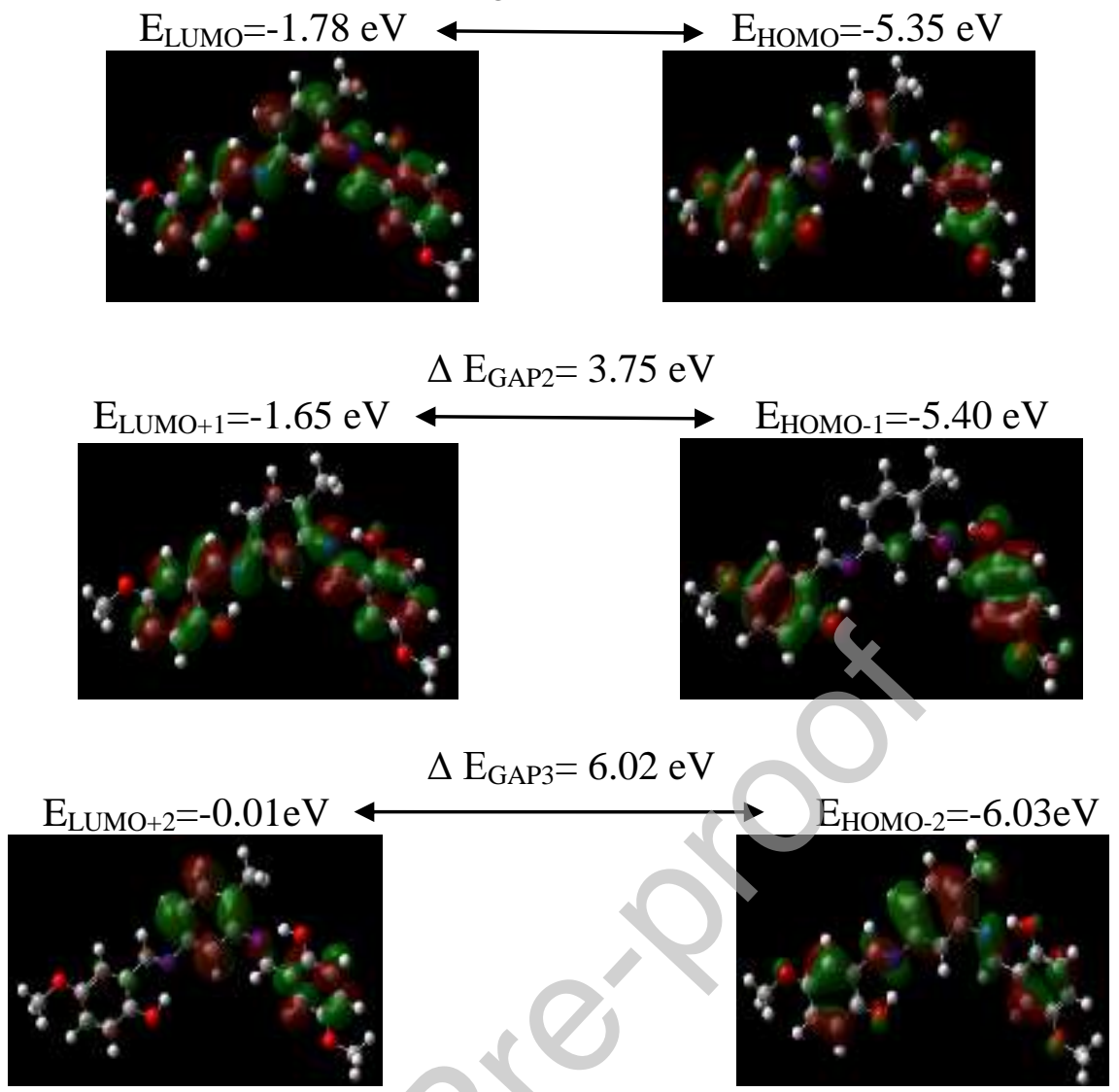

Figure.7. Molecular orbitals of the ligand $\mathrm{L}$ and theirs related energies.

Table.5. Physico-chemical parameters calculated theoretically characteristic of the ligand L.

\begin{tabular}{ll}
\hline Quantum parameters & \\
\hline $\mathrm{E}_{\mathrm{Tot}}(\mathrm{eV})$ & -35377.438 \\
$\mathrm{E}_{\mathrm{HOMO}}(\mathrm{eV})$ & -5.348 \\
$\mathrm{E}_{\mathrm{LUMO} O}(\mathrm{eV})$ & -1.782 \\
$\Delta \mathrm{E}_{\mathrm{GAPl}}(\mathrm{eV})$ & 3.566 \\
Ionization Energy $(\mathrm{I})_{\text {Electron Affinity }(\mathrm{A})}$ & 5.348 \\
Electronegativity $(\chi)$ & 1.782 \\
Chemical Potential $(\mu)$ & 3.565 \\
Chemical Hardness $(\eta)$ & -3.565 \\
Chemical Softness $(\mathrm{S})$ & 1.783 \\
Electrophilicity Index $(\omega)$ & 0.561 \\
\hline
\end{tabular}

\subsection{Electrochemical study}

\subsubsection{Electrochemical properties}

The electrochemical properties of the ligand $\mathrm{L}$ were investigated utilizing the cyclic voltammetry. This study was recorded in the potential range from +1600 to $-2000 \mathrm{mV} / \mathrm{SCE}$ with the scan rate of $50 \mathrm{mV} / \mathrm{s}$. The cyclic voltammogram of the compound $\mathrm{L}$ under nitrogen 
atmosphere shows an anodic peak at $1.093 \mathrm{~V} / \mathrm{SCE}$ is attributed to the oxidation of the phenolic groups of the ligand L [16] and cathodic peak at $-1.708 \mathrm{~V} / \mathrm{SCE}$ is attributed to the reduction of azomethine group $(\mathrm{C}=\mathrm{N})[43,53]$. Also, the cyclic voltammogram of ferrocene was carried out, it has a reversible $\mathrm{OxFc} / \mathrm{RedFc}^{+}$process at the potential $0.530 / 0.396 \mathrm{~V} / \mathrm{SCE}$ with $\mathrm{E}_{1 / 2}$ equal to $0.460 \mathrm{~V}$ (Figure 8).

A relationship between the electrochemical behavior and the DFT calculation is possible since a correlation can be established between the theoretical orbital energies and the oxidation and reduction potentials. The HOMO, LUMO energies, and the gap energy of the compound $\mathrm{L}$ were estimated experimentally using the oxidation and reduction potentials according to the following empirical relations [54].

$$
\begin{aligned}
& \mathrm{E}_{\mathrm{HOMO}}=-\left[\mathrm{E}_{\mathrm{ox}}-\mathrm{E}_{1 / 2}(\text { ferrocene })+4.8\right] \\
& \mathrm{E}_{\mathrm{LUMO}}=-\left[\mathrm{E}_{\mathrm{red}}-\mathrm{E}_{1 / 2}(\text { ferrocene })+4.8\right]
\end{aligned}
$$

The experimental values estimated for the gap energy, HOMO, and LUMO energies using the voltammogram of the ligand are $2.80 \mathrm{eV},-5.433 \mathrm{eV},-2.632 \mathrm{eV}$ respectively, and are comparable with the theoretical values (Table 5).

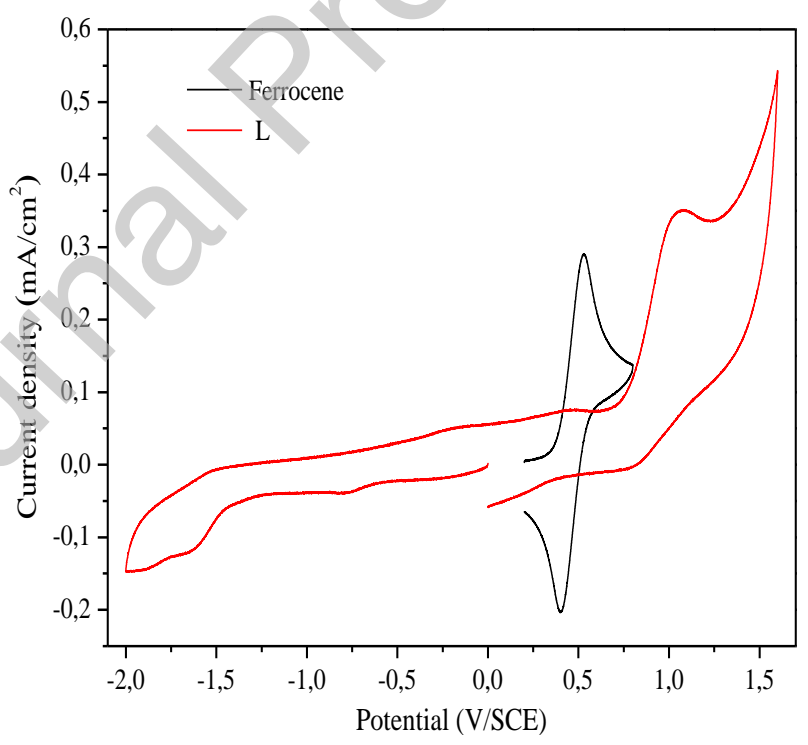

Figure.8. Cyclic voltammograms of the compound $\mathrm{L}$ and the ferrocene in $\mathrm{LiClO}_{4}-\mathrm{DMF}$ $0.1 \mathrm{M}$ at scan rate $50 \mathrm{mV} / \mathrm{s}$.

\subsubsection{Superoxide radical scavenging by using a cyclic voltammetric method}

The cyclic voltammogram in presence of the molecular oxygen is recorded comparatively to its absence in DMF solution and containing $0.1 \mathrm{M} \mathrm{LiClO}_{4}$ as supporting electrolyte, it shows a cathodic peak located at $-1.190 \mathrm{~V} / \mathrm{SCE}$ and anodic peak at $0.359 \mathrm{~V} / \mathrm{SCE}$ 
(Figure 9). The peak at $0.359 \mathrm{~V} / \mathrm{SCE}$ is attributed to the reoxidation of the molecular oxygen, confirming that the redox couple $\left(\mathrm{O}_{2} / \mathrm{O}_{2}{ }^{-}\right)$is irreversible [55].

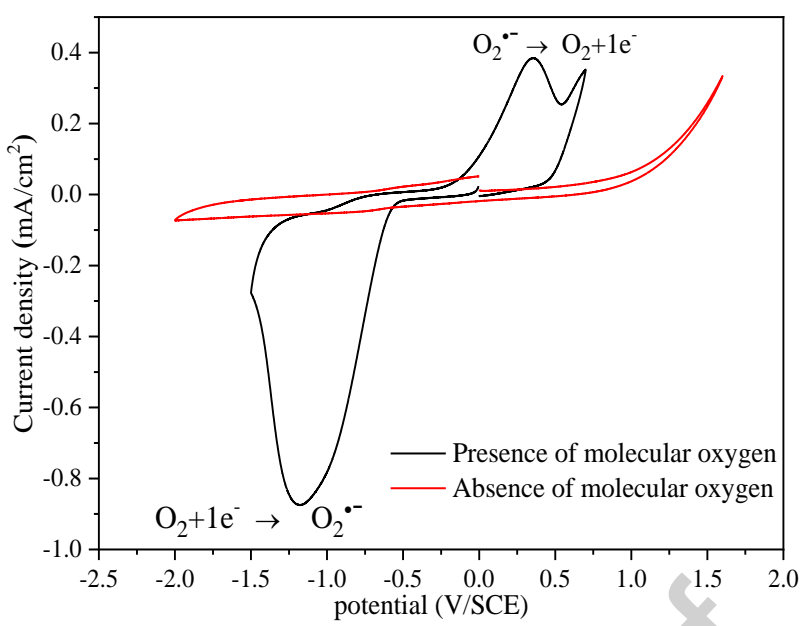

Figure.9. Cyclic voltammograms in $\mathrm{DMF}$ and $\mathrm{LiClO}_{4} 0.1 \mathrm{M}$, in presence and absence of molecular oxygen.

From the Figure 10, the cyclic voltammograms of molecular oxygen in the presence and in the absence of the tested samples ( $\mathrm{L}$ and BHT) at the concentration of $10^{-3} \mathrm{M}$, a decrease can be easily observed on the anodic peak according to the order ( $i_{p a}$ black $>i_{p a}$ BHT $>\mathrm{i}_{\mathrm{pa}} \mathrm{L}$ ), which means that the tested samples react with $\mathrm{O}_{2}{ }^{--}$radical.

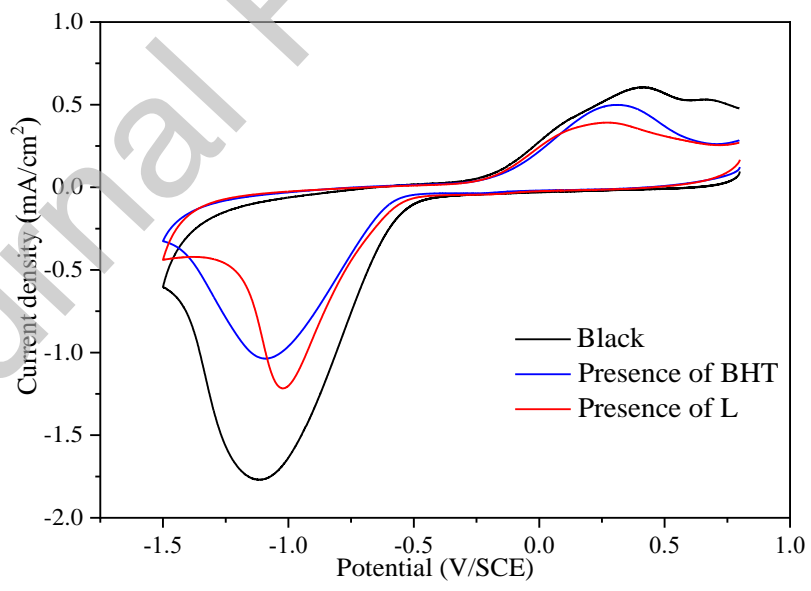

Figure.10. Cyclic voltammograms of DMF with $\mathrm{O}_{2}{ }^{--}$radical in presence and absence of the tested samples.

The mechanism of the reaction was described in the literature [24]. Whereas the superoxide anion is generated by one-electron reduction of the air molecular oxygen dissolved in DMF, and by the electrochemical way the antioxidant reacts with the superoxide radical according to the following series of reactions ( $a, b$ and $c)$ :

$$
\mathrm{O}_{2}+\mathrm{e}^{-} \rightarrow \mathrm{O}_{2}^{\cdot-}
$$




$$
\begin{aligned}
& \mathrm{O}_{2}{ }^{--}+\mathrm{AH} \rightarrow\left[\mathrm{A}-\mathrm{HO}_{2}{ }^{-}\right] \rightarrow \mathrm{A}^{-}+\mathrm{HO}_{2}{ }^{-} \\
& \mathrm{HO}_{2}{ }^{-}+\mathrm{AH} \rightarrow \mathrm{H}_{2} \mathrm{O}_{2}+\mathrm{A}^{-}
\end{aligned}
$$

\section{Effect of variation in concentration}

To determine the Gibbs free energy $\left(\Delta \mathrm{G}^{\circ}\right)$, binding constant $\left(\mathrm{K}_{\mathrm{b}}\right)$ and the $\mathrm{RSAO}_{2}{ }^{-} \%$, we followed the evolution of the current density as a function of the concentration of $\mathrm{L}$ and BHT. The concentration increase of the tested samples is accompanied by a decrease in the anodic current, and also an increase in the percentage of superoxide radical scavenging $\left(\mathrm{RSAO}_{2}{ }^{*} \%\right)$ (Table 6). The extrapolating of the $\log \left(1 / \mathrm{C}_{\text {test }}\right)=f\left(\log \left(\mathrm{i}_{\mathrm{pa}} /\left(\mathrm{i}_{\mathrm{pa}}^{\circ}-\mathrm{i}_{\mathrm{pa}}\right)\right)\right.$ curve allowed us to determine the constant $\mathrm{K}_{\mathrm{b}}$ (Figure 11). The values of $\Delta \mathrm{G}^{\circ}$ were calculated from equation (11). The compound L and the BHT exhibit comparable progress in this activity (Figure 12), also their Gibbs free energy is almost comparable (Table 6), and its negative value proved the spontaneity of the antiradical reaction.

Table.6. Thermodynamic parameters (Gibbs free energy $\left(\Delta G^{\circ}\right)$, binding constant $\left(K_{b}\right)$ and the $\mathrm{RSAO}^{*}(\%)$ evaluation for the compound L and for the BHT.

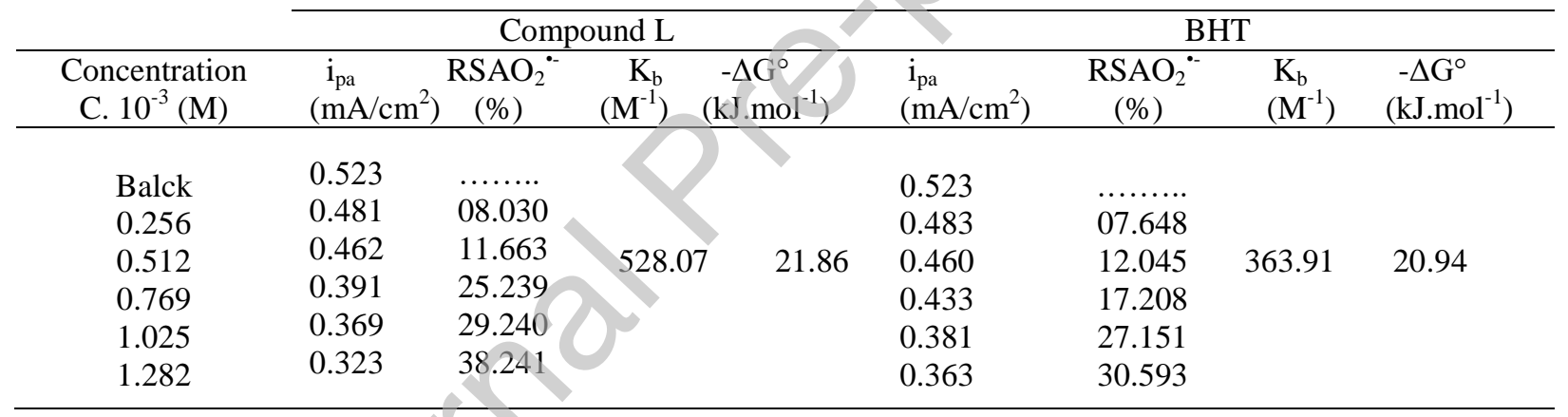

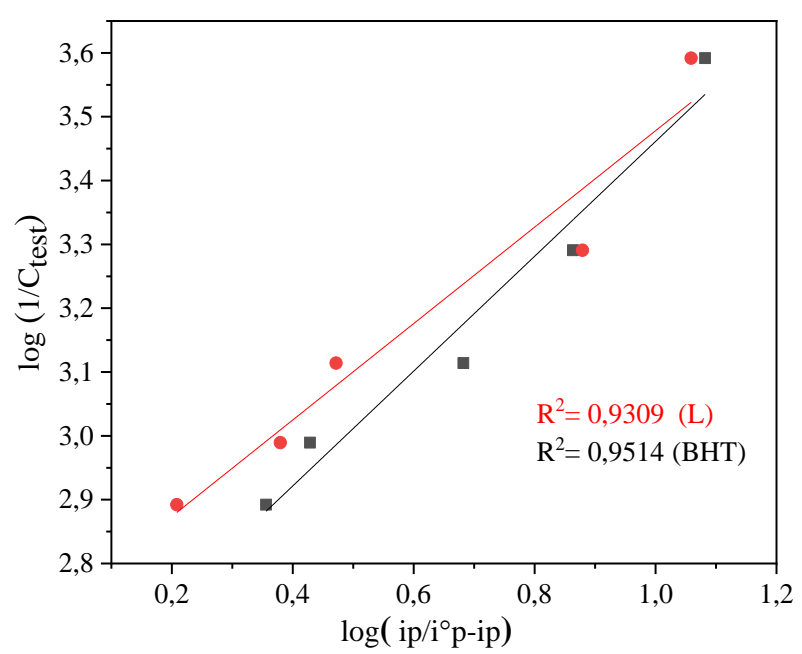

Figure.11. $\log \left(\mathrm{ip} /\left(\mathrm{i}^{\circ} \mathrm{p}\right.\right.$-ip) $)$ vs $\log \left(1 / \mathrm{C}_{\text {test }}\right)$ for $\mathrm{L}$ and $\mathrm{BHT}$. 


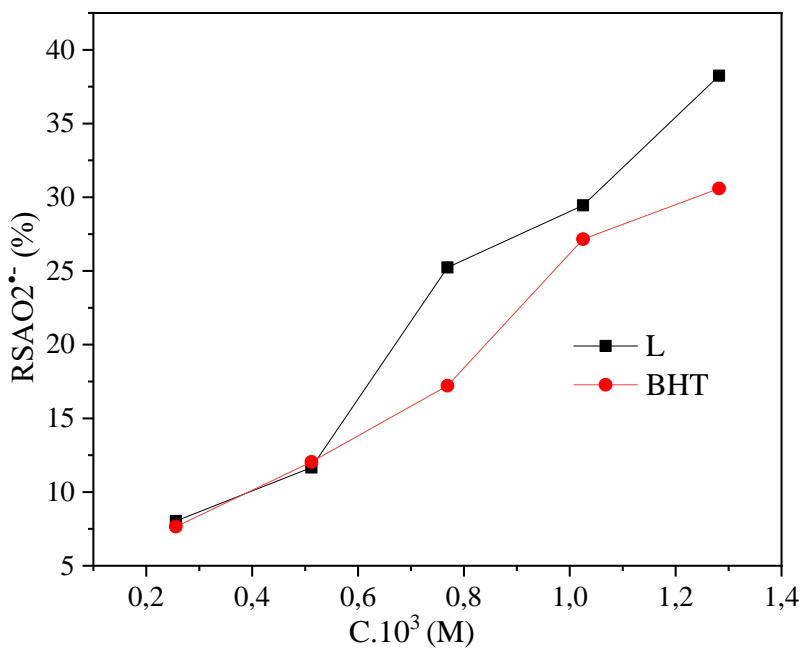

Figure.12. Evolution of the $\mathrm{RSAO}_{2}{ }^{\circ-}(\%)$ with various concentrations of $\mathrm{L}$ and BHT compounds.

\subsection{Antioxydants activities}

\subsubsection{DPPH' radical scavenging assay}

DPPH is a stable free radical containing an odd electron in its structure and usually used for the detection of radical scavenging activity. The $\mathrm{DPPH}^{\bullet}$ radical has violet-color, its color turns yellow when reduced by a donor of proton [56] (reaction d).

$$
\mathrm{DPPH}^{\bullet}+\mathrm{AH} \rightarrow \mathrm{DPPH}(\mathrm{H})+\mathrm{A}^{\bullet}
$$

The results of the DPPH test show that the effective concentration $(\mu \mathrm{g} / \mathrm{ml})$ of the compound $\mathrm{L}\left(\mathrm{EC}_{50}{ }^{1}=210 \pm 31.607\right)$ has poor antioxidant activity compared to the effective concentration of the $\mathrm{BHT}$ standard $\left(\mathrm{EC}_{50}{ }^{1}=57.119 \pm 5.361\right)$ (Table 7) [25]. This large difference between the two can be explained by the high ability of BHT standard to reduce the DPPH radical ( $1 \mathrm{~mol}$ of BHT reduces $3 \mathrm{~mol}$ of DPPH free radical). It is well known that the BHT is one of the best antioxidants [57]. However, the percent of scavenging effect (\%) increases with the increase of the concentration of the compound L (Table 8).

Table.7. $\mathrm{EC}_{50}$ of the tested samples L, BHT and ascorbic acid in the antioxidant activities.

\begin{tabular}{ccccc}
\hline Samples & DPPH. $\mathrm{EC}_{50}{ }^{1}$ & $\mathrm{ABTS} \mathrm{EC}_{50}{ }^{2}$ & Reducing power $\mathrm{EC}_{50}{ }^{3}$ & $\mathrm{OH} . \mathrm{EC}_{50}{ }^{4}$ \\
\hline $\mathrm{L}$ & $210.477 \pm 31.607$ & $34 \pm 5.541$ & $73.238 \pm 3.363$ & $166.721 \pm 66.231$ \\
BHT & $57.310 \pm 5.361$ & $8.177 \pm 0.235$ & $22.182 \pm 3.519$ & ----- \\
Ascorbicacid & ----- & ----- & ----- & $293.678 \pm 1.485$ \\
\hline
\end{tabular}

$\mathrm{EC}_{50}{ }^{1}$ : effective concentration $(\mu \mathrm{g} / \mathrm{ml})$ at the percent inhibition is $50 \%$ of DPPH activity.

$\mathrm{EC}_{50}{ }^{2}$ : effective concentration $(\mu \mathrm{g} / \mathrm{ml})$ at the percent inhibition is $50 \%$ of ABTS activity.

$\mathrm{EC}_{50}{ }^{3}$ : effective concentration $(\mu \mathrm{g} / \mathrm{ml})$ at the absorbance is 0.5 .

$\mathrm{EC}_{50}{ }^{4}$ : effective concentration $(\mu \mathrm{g} / \mathrm{ml})$ at the percent inhibition is $50 \%$ of hydroxyl radical activity. 
Table.8. Evolution of the percent inhibition (\%) for the compound L and BHT.

\begin{tabular}{cc|cc}
\hline \multicolumn{2}{c|}{ Compound L } & \multicolumn{2}{c}{ BHT } \\
\hline Concentration $(\mu \mathrm{g} / \mathrm{ml})$ & $(\%) \mathrm{DPPH}$ & Concentration $(\mu \mathrm{g} / \mathrm{ml})$ & $(\%) \mathrm{DPPH}$ \\
7 & 39.448 & 20 & 37.026 \\
20 & 42.306 & 27 & 39.130 \\
60 & 43.469 & 33 & 44.133 \\
200 & 48.620 & 67 & 79.710 \\
400 & 58.828 & 133 & 79.310 \\
470 & 63.310 & 270 & 93.314 \\
530 & 67.035 & 333 & 93.548 \\
700 & 70.422 & 500 & 93.454 \\
870 & 74.875 & 600 & 93.127 \\
& & 700 & 93.595 \\
\hline
\end{tabular}

\subsubsection{ABTS radical scavenging assay}

The ABTS test has almost the same principle as the DPPH test, but the $\mathrm{ABTS}^{{ }^{+}}$has higher reactivity than $\mathrm{DPPH}^{\circ}$. The antioxidant reduces $\mathrm{ABTS}^{\circ+}$ to $\mathrm{ABTS}$ according to the following reaction (e) [58].

$$
\mathrm{ABTS}^{\cdot+}+\mathrm{AH} \rightarrow \mathrm{ABTS}+\mathrm{A}^{\bullet}+\mathrm{H}^{+}
$$

According to Table 7, the effective concentration of the compound $\mathrm{L}\left(\mathrm{EC}_{50}{ }^{2}=34 \pm 5.541\right)$ has moderate antioxidant activity compared to the BHT standard $\left(\mathrm{EC}_{50}{ }^{2}=8.177 \pm 0.235\right)$.

\subsubsection{Hydroxyl radical scavenging assay}

The hydroxyl radical is generated by the system $\left(\mathrm{Fe}^{2+} / \mathrm{H}_{2} \mathrm{O}_{2}\right)$ as shown in the following reactions [59]:

$$
\begin{aligned}
& \mathrm{H}_{2} \mathrm{O}_{2}+\mathrm{Fe}^{2+} \rightarrow \mathrm{Fe}^{3+}+\mathrm{OH}^{\bullet}+\mathrm{OH}^{-} \\
& \mathrm{OH}^{\cdot}+\mathrm{Fe}^{2+} \rightarrow \mathrm{OH}^{-}+\mathrm{Fe}^{3+} \\
& \mathrm{OH}^{\cdot}+\mathrm{H}_{2} \mathrm{O}_{2} \rightarrow \mathrm{H}_{2} \mathrm{O}+\mathrm{OOH}^{\cdot} \\
& \mathrm{OOH}^{\cdot}+\mathrm{H}_{2} \mathrm{O}_{2} \rightarrow \mathrm{H}_{2} \mathrm{O}+\mathrm{OH}^{\bullet}+\mathrm{O}_{2}
\end{aligned}
$$

The hydroxyl radical has a potent tendency to taking the hydrogen atom whenever possible and forming a stable water molecule automatically [60].

$$
\mathrm{OH}^{\bullet}+\mathrm{AH} \leftrightarrow \mathrm{H}_{2} \mathrm{O}+\mathrm{A}^{\bullet}
$$


The compound $\mathrm{L}$ has a high antioxidant activity compared to the ascorbic acid standard. The $\mathrm{EC}_{50}{ }^{4}$ values of the compound (L) and ascorbic acid are 166.721 \pm 66.231 , $293.678 \pm 1.485$ respectively (Table 7 ).

\subsubsection{Reducing power}

The presence of the antioxidant led to the reduction of ferricyanide $\left(\mathrm{Fe}^{3+}\right)$ to the ferrous form $\left(\mathrm{Fe}^{2+}\right)$ with a change of color from yellow to various shades of blue-green [61].

The reducing power of the compound L is lower than the BHT standard, this was clear from the effective concentration value $\left(\mathrm{EC}_{50}{ }^{3}(\mu \mathrm{g} / \mathrm{ml})\right)$ it is $73.238 \pm 3.363 ; 22.182 \pm 3.519$ for $\mathrm{L}$ and BHT respectively at the absorbance 0.5 (Table 7). Nevertheless, the L compound has a good ability to bodice free radicals.

\subsection{5. $\beta$-carotene bleaching test}

In this test, the free radicals (hydroperoxides) is the result of oxidation of linoleic acid [62]. These hydroperoxides oxidize the $\beta$-carotene and decrease the orange color of $\beta$ carotene. The role of the antioxidant is to minimize the oxidation of the $\beta$-carotene. In the presence of the BHT the absorbances of the $\beta$-carotene solution are stayed stable in the incubation period, while in the presence of the negative control samples the $\beta$-carotene solution is oxidized quickly. But in the presence of the compound $\mathrm{L}$ the $\beta$-carotene solution is oxidized slowly (Figure 13).

After 24 hours, the results permit to classify the antioxidant activity of the samples in increasing order: $\mathrm{H}_{2} \mathrm{O}<\mathrm{EtOH}<\mathrm{L}<$ BHT. The compound L shows a good antioxidant activity compared to the BHT and the negative control samples.

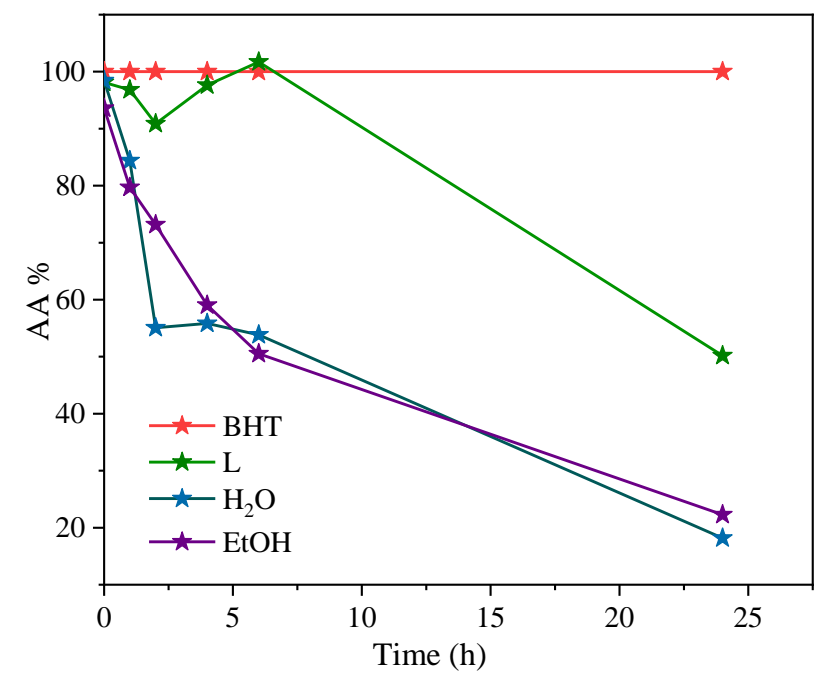

Figure.13. Antioxidant activity of L, BHT and negative controls in (ß-CBTS). 


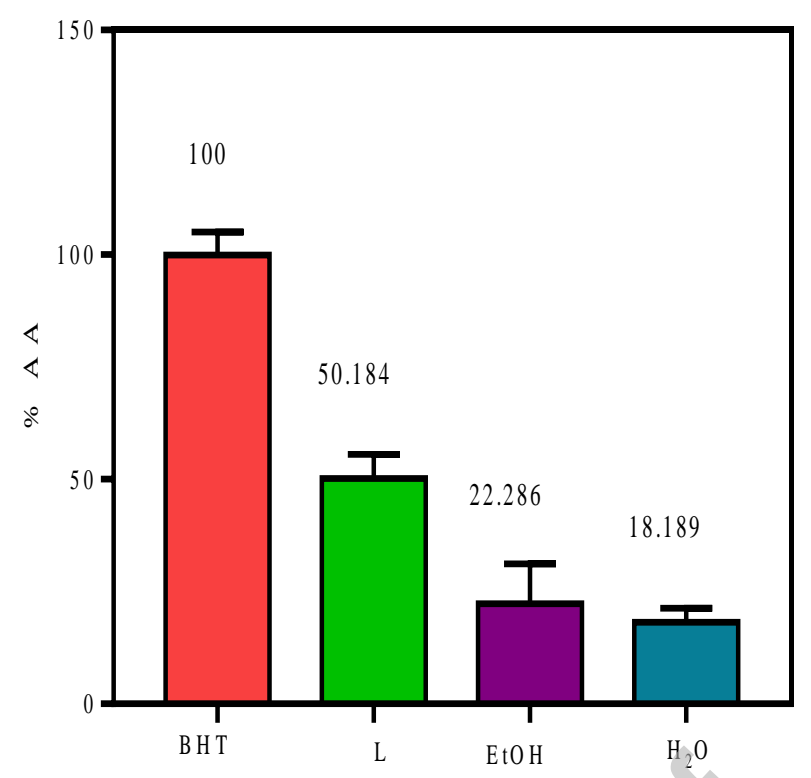

Figure.14. Antioxidant activity (AA \%) determined after $24 \mathrm{~h}$, for L, BHT and negative Controls.

\section{Conclusion}

In this research, new Schiff base 2,2'-((1E,1'E)-((4-methyl-1,3-phenylene) bis (benzylidene)) bis (methylethylidene)) bis (4-methoxyphenol) derived from 2,4diaminotoluene, and 2-hydroxy-5-methoxy benzaldehyde was synthesized, with significant yield and characterized by different spectroscopic techniques. The structure was resolved by the XRD analysis and this illustrates that the compound crystallizes in monoclinic system by asymmetric unit, the 3D network is maintained principally through intermolecular hydrogen bonds and $\pi-\pi$ interaction, forming a complex supramolecular network. The experimental structure was compared to the optimized one and the results proved a good consistency between them.

The IR, ${ }^{1} \mathrm{H}-\mathrm{NMR},{ }^{13} \mathrm{C}-\mathrm{NMR}$ spectroscopies assigned well the compound and are in good agreement with the DFT results, as like the position of the phenolic group (at 3556 (exp)/3097 (cal) $\mathrm{cm}^{-1}$ ) and the azomethine group (at 1577 (exp)/1612 (cal) $\mathrm{cm}^{-1}$ ) in vibration analysis, the $-\mathrm{OH}$ group (at $12.47 ; 12.63$ (exp)/12.24; 12.34 (cal) ppm for $\mathrm{H}$ ) and $-\mathrm{CH}=\mathrm{N}$ - (at 8.97; 9.01 (exp)/8.54; 8.37 (cal) ppm for H), and (163.16; 163.78 (exp)/148.51; 154.58 (cal) ppm for C) in NMR analysis. These groups confirm the formation of $\mathrm{L}$.

The DFT calculation was a tool for plotting the molecular orbitals, and for the calculation of their related energies, these last were exploited as a route for the explanation of the electrochemical behavior and the chemical reactivity of the synthesized Schiff base. The 
electrochemical study showed that the ligand has a reduction peak at $-1.708 \mathrm{~V} / \mathrm{SCE}$ and an oxidation peak at 1.093V/SCE. A correlation was established between cyclic voltammetry peaks and frontier orbitals energies, through it, we can determine the gap energy, the value of this last one reflects the good reactivity of the compound L.

The antioxidant activity of this compound has been examined by several chemical tests like DPPH, ABTS, Hydroxyl radical scavenging test, the reducing power test, the $\beta$ carotene bleaching test, and cyclic voltammetry method for measures the scavenging effect of superoxide radical. The compound L showed an excellent antioxidant activity than the standard ascorbic acid. The antioxidant activity values illustrated the good compound's ability to sweep the free radicals especially in the $\beta$-carotene and ABTS tests owing to its structure containing the hydroxyl group attached to the aromatic ring that participates critically to the antioxidant activity.

The cyclic voltammetry method measured the scavenging effect toward superoxide anion radical and indicated a strong interaction between the $\mathrm{O}_{2}{ }^{-}$and the compound $\mathrm{L}$. This was demonstrated by the high value of $\mathrm{K}_{\mathrm{b}}$. On the other hand, the negative sign of $\Delta \mathrm{G}^{\circ}$ proved the spontaneity of the antiradical reaction.

\section{Acknowledgement}

The Authors would like to thank Professor Lahcene OUAHAB for the help to access the crystallography at Institut of Chemical Sciences of the University of Rennes 1 CDiFX France.

\section{CREDIT AUTHOR STATEMENT}

ABDELMADJID Madi Amira has due the experiments, writted and interpretated results in the paper.

BENGHANEM Fatiha has proposed the aim of research, followed the electrochemical studies, interpreted results, reviewed and edited the paper.

HAFFAR Djahida has contributed in the research, followed the electrochemical studies, interpreted results, reviewed and edited the paper.

GHEDJATI samira has followed and interpreted the experimental work on biological activity.

BOURZAMI Riadh has followed and interpreted the crystallographic study.

TOUKAL Linda has contributed in the theoretical calculations by DFT and interpreted the results.

DORCET Vincent has resolved the crystallographic structure. 


\section{References}

[1] H. Schiff, Mittheilungen aus dem universita laboratorium in Pisa: Eine neue reihe organischer basen. Justus. Liebigs. Ann. Chem. 131 (1864) 118-119.

http://dx.doi.org/10.1002/jlac.18641310113

[2] G. Ceyhana, C. Celikb, S. Urus, I. Demirtas, M. Elmastas, M. Tümera, Antioxidant, electrochemical, thermal, antimicrobial and alkane oxidation properties of tridentate Schiff base ligands and theirmetal complexes, Spectrochim. Acta Part A: Mol. Biomol. Spectroscopy. 81 (2011) 184-198. https://doi.org/10.1016/j.saa.2011.05.106

[3] C.M. DaSilva, D.L. Da Silva, L.V. Modolo, R.B. Alves, M.A. De Resende, C.V.B. Martins, Â. De Fàtima, Schiff bases: A short review of their antimicrobial activities, J. Adv. Res. 2 (2011) 1-8. https://doi.org/10.1016/j.jare.2010.05.004

[4] A.A. Jarrahpour, M. Motamedifar, K. Pakshir, N. Hadi, M. Zarei, Synthesis of Novel Azo Schiff Bases and Their Antibacterial and Antifungal Activities, Molecules 9 (2004) 815-824. https://doi.org/10.3390/91000815

[5] Y. Zhang, B. Zou, Z. Chen, Y. Pan, H. Wang, H. Liang, X. Yi, Synthesis and anti oxidant activities of novel 4-Schiff base-7-benzyloxy-coumarin derivatives, Bioorganic \& Med. Chem. Lett. 21 (2011) 6811-6815. https://doi.org/10.1016/j.bmcl.2011.09.029

[6] K.N. Mohana, L. Mallesha, D.M. Gurudatt, Synthesis and antimicrobial activity of 5aminoquinoline and 3-amino phenol derivatives, International Journal of Drug Design and Discovery. 2 (3) (2011) 584-590.

[7] A.S. Alturiqi, A.M.A. Alaghaz, M.E. Zayed, R.A. Ammar, Synthesis, characterization, biological activity, and corrosion inhibition in acid medium of unsymmetrical tetradentate $\mathrm{N}_{2} \mathrm{O}_{2}$ Schiff base complexes, J. Chin. Chem. Soc. (2018) 1-15.

https://doi.org/10.1002/jiccs.201800027

[8] H. Baykara, S. Ilhan, A. Levent, M.S. Seyitoglu, S.Özdemir, V. Okumus, A. Öztomsuk, M. Cornejo, Synthesis, characterization and experimental, theoretical, electrochemical, antioxidant and antibacterial study of a new Schiff base and its complexes, Spectrochim. Acta A Mol. Biomol. Spectrosc. 130 (2014) 270-279. https://doi.org/10.1016/j.saa.2014.03.094

[9] S. Ilhan, H. Baykara, M.S. Seyitoglu, A. Levent, S. Özdemir, A. Dündar, A. Öztomsuk, M.H. Cornejo, Preparation, spectral studies, theoretical, electrochemical and antibacterial investigation of a new Schiff base and its some metal complexes, J. Mol. Struct. 1075 (2014) 32-42. http://dx.doi.org/10.1016/j.molstruc.2014.06.062

[10] R.P. Mason, Imaging free radicals in organelles, cells, tissue, and in vivo with immunospin trapping, Redox. Biol. 8 (2016) 422-429. https://doi.org/10.1016/j.redox.2016.04.003

[11] K.F. Gey, Prospects for the prevention of free radical disease, regarding cancer and cardiovasculardisease, British Medical Bulletin. 49 (1993) 679-699.

https://doi.org/10.1093/oxfordjournals.bmb.a072640 
[12] M. Valko, D. Leibfritz, J. Moncola, M.T.D. Cronin, M. Mazura, J. Telser, Free radicals and antioxidants in normal physiological functions and human disease, Inter. J. Biochem. Cell Biol. 39 (2007) 44-84. https://doi.org/10.1016/j.biocel.2006.07.001

[13] F. Sonmez, Z. Gunesli, B.Z. Kurt, I. Gazioglu, D. Avci, M. Kucukislamoglu, Synthesis, antioxidant activity and SAR study of novel spiro-isatin - based Schiff bases, Mol. Div. 23 (2019) 829-844. https://doi.org/10.1007/s11030-018-09910-7

[14] M. Taha, N.H. Ismail, W. Jamil, H. Rashwan, S.M. Kashif, A.A. Sain, M.I. Adenan, E. Anouar, M. Ali, F. Rahim, K.M. Khan, Synthesis of novel derivatives of 4-methylbenz imidazole and evaluation of their biological activities, Eur. J. Med. Chem. 84 (2014) 731-738. https://doi.org/10.1016/j.ejmech.2014.07.078

[15] Y.Z. Tang, Z.Q. Liu, Quantitative structure-activity relationship of hydroxyl-substituent Schiff bases in radical-induced hemolysis of human erythrocytes, Cell. Biochem. Funct. 26 (2008) 185-191. https://doi.org/10.1002/cbf.1426

[16] R. Benramdane, F. Benghanem, A. Ourari, S. Keraghel, G. Bouet, Synthesis and characterization of a new Schiff base derived from 2, 3-diaminopyridine and 5methoxysalicylaldehyde and its $\mathrm{Ni}(\mathrm{II}), \mathrm{Cu}$ (II) and $\mathrm{Zn}$ (II) complexes. Electrochemical and electrocatalytical studies, J. Coord. Chem. 68 (2015) 560-572.

https://doi.org/10.1080/00958972.2014.994514

[17] A.V. Nemtareva, V.F. Mironova, R.R. Fayzullina, I.A. Litvinova, R.Z. Musina, Reactions of Arylenedioxytrihalophosphoranes with Acetylenes: XV.1 Reaction of 2, 2, 2-

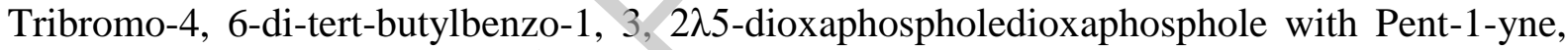
Russ. J. Gen. Chem. 88 (2018) 2290-2295. https://doi.10.1134/s1070363218110075

[18] A.D. Becke, Density-functional thermochemistry. The role of exact exchange, J. Chem. Phys. 98 (1993) 5648-5652. https://doi.org/10.1063/1.464913

[19] C. Lee, W. Yang, R.G. Parr, Development of the Colle-Salvetti correlation-energy formula into a functional of the electron density, Phys. Rev. 37 (1988) 785-789.

https://doi.org/10.1103/PhysRevB.37.785

[20] D.C. Young, Computational Chemistry: A Practical Guide for Applying Techniques to Real-World Problems, John Wiley \& Sons, Inc, 2001.

[21] S.K. Wolff, T. Ziegler, Calculation of DFT-GIAO NMR shifts with the inclusion of spinorbit coupling, J. Chem. Phys. 109 (1988) 895-905. https://doi.org/10.1063/1.476630

[22] E.F. Silva-Júnior, D.L. Silva, P.F.S. Santos-Júnior, I.J.S. Nascimento, S.W.D. Silva, T.L. Balliano, T.M. Aquino, J.X. Araújo-Júnior, Crystal structure and DFT calculations of 4, 5-dichloropyridazin-3-(2H)-one, J. Chem. Pharm. Res. 8 (2016) 279-286.

[23] C. Le Bourvellec, D. Hauchard, A. Darchen, J.L. Burgot, M.L. Abasq, Validation of a new method using the reactivity of electrogenerated superoxide radical in the antioxidant capacity determination of flavonoids, Talanta. 75 (2008) 1098-1103.

https://doi.org/10.1016/j.talanta.2008.01.007 
[24] S. Ahmed, F. Shakeel, Antioxidant Activity Coefficient, Mechanism, and Kinetics of Different Derivatives of Flavones and Flavanones Towards Superoxide Radical, Czech J. Food. Sci. 30 (2012) 153-163. https://doi.org/10.17221/447/2010-CJFS

[25] A.J. Muhammad, D. Ahmed, S. Yousuf, N. Tabassum, M.T. Qamar, Synthesis, crystal structures, Hirshfeld surface analysis and spectroscopic studies of two Schiff bases of anisaldehyde and their urease and acetylcholinesterase inhibitory and antioxidant properties, Heliyon. 5 (2019) e01758. https://doi.org/10.1016/j.heliyon.2019.e01758

[26] T.C. Shekhar, G. Anju, Antioxidant Activity by DPPH Radical Scavenging Method of Ageratum conyzoides Linn. Leaves, American Journal of Ethnomedicine. 1 (4) (2014) 244249.

http://citeseerx.ist.psu.edu/viewdoc/download?doi=10.1.1.678.4869\&rep=rep1\&type=pdf

[27] B.Z. Kurt, I. Gazioglu, F. Sonmez, M. Kucukislamoglu, Synthesis, antioxidant and anticholinesterase activities of novel coumarylthia-zole derivatives, Bioorg. Chem. 59 (2015) 80-90. https://doi.org/10.1016/j.bioorg.2015.02.002

[28] R. Re, N. Pellegrini, A. Proteggeente, A. Pannala, M.Yang, C. Rice-Evans, Antioxidant Activity Applying an Improved ABTS Radical Cation Decolorization Assay, Free. Radic. Biol. Med. 26 (1999) 1231-1237. https://doi.org/10.1016/S0891-5849(98)00315-3

[29] B.T. Aluko, O.I. Oloyede, A.J. Afolayan, Polyphenolic Contents and Free Radical scavenging Potential of Extracts from Leaves of Ocimum americanum L, Pakis. J. biol. Sci. 16 (2013) 22-30. https://doi.org/10.3923/pjbs.2013.22.30

[30] I.C.F.R. Ferreira, P. Baptista, M. Vilas-Boas, L. Barros, Free-radical scavenging capacity and reducing power of wilde dible mushrooms from north east Portugal: Individual cap and stipe activity, Food Chem. 100 (2007) 1511-1516.

https://doi.org/10.1016/j.foodchem.2005.11.043

[31] A. Dapkevicius, R. Venskutonis, T.A. Van Beek, J.P.H. Linssen, Antioxidant Activity of Extracts Obtained by Different Isolation Procedures from some Aromatic Herbs Grown in Lithuania, J. Sci. Food. Agric. 77 (1998) 140-146. https://doi.org/10.1002/(SICI)10970010(199805)77:1<140::AID-JSFA18>3.0.CO;2-K

[32] M. Kelen, B. Tepe, Chemical composition, antioxidant and antimicrobial properties of the essential oils of three Salviaspecies from Turkish flora, Bioresource Technol. 99 (2008) 4096-4104. https://doi.org/10.1016/j.biortech.2007.09.002

[33] H. Ünvera, M Yıldızb, B. Dülger, Ö. Özgend, E. Kendid, T.N. Durlua, Spectroscopic studies, antimicrobial activities and crystal structures of N-(2-hydroxy-3-methoxybenzali dene) 1-aminonaphthalene, J. Mol. Struct. 737 (2005) 159-164.

https://doi.org/10.1016/j.molstruc.2004.10.030

[34] A.D. Khalaji, A.N. Chermahini, K. Fejfarova, M. Dusek, Synthesis, characterization, crystal structure, and theoretical studies on Schiff-base compound 6-[(5-Bromopyridin-2-yl) iminomethyl] phenol. Struct Chem. 21 (2010) 153-157. https://doi.org/10.1007/s11224-009$\underline{9554-5}$ 
[35] A.D. Khalaji, K. Fejfarova, M. Dusek, A.N. Chermahini, Synthesis, Crystal Structure and Conformational Studies of Schiff-Base Compound 2-\{[4-(Phenyldiazenyl) Phenyl] Iminomethyl \}-5-Bromophenol, J. Chem. Crystallogr. 42 (2012) 136-140. https://doi.org/10.1007/s10870-011-0214-4

[36] L. Chęcińska, J. Lewkowski, M. Małecka, M. Dzięgielewski, Synthesis and Characterization of N, N'-terephthalidenebis (o-aminoaniline): Crystal Structures of Its Two Polymorphic Forms Controlled by Changing the Crystallization Solvent, J. Chem. Crystallogr. 43 (2013) 421-428. https://doi.org/10.1007/s10870-013-0439-5

[37] E. Pahonțu, D.C. Ilieș, S. Shova, C. Paraschivescu, M. Badea, A. Gulea, T. Roșu, Synthesis, Characterization, Crystal Structure and Antimicrobial Activity of Copper(II) Complexes with the Schiff Base Derived from 2-Hydroxy-4-Methoxybenzaldehyde, Molecules 20 (2015) 5771-5792. https://doi.org/10.3390/molecules20045771

[38] A.L.A. Kala, N.V. Harohally, S. Naveen, M. Ramegowda, N.K. Lokanath, O-hydroxy Schiff Bases Derived from 2-Hydroxy-4-methoxy Benzaldehyde: Synthesis, X-Ray Studies and Hydrogen Bonding Attributes, Molecular Crystals and Liquid Crystals. 629 (2016) 146157. https://doi.org/10.1080/15421406.2015.1107814

[39] A.E. Şabik, M. Karabörk, G. Ceyhan, M. Tümer, M. Dığrak, Polydentate Schiff Base Ligands and Their La(III) Complexes: Synthesis, Characterization, Antibacterial, Thermal, and Electrochemical Properties, Int. J. Inorg. Chem. 2012 (2012) 1-1.

https://doi.org/10.1155/2012/791219

[40] I. Jirjees, S.A. Ali, H.A. Mahdi, Synthesis, Characterization of Schiff Base and its Complexes Derived from 4-Aminoantipyrine and using in Extraction of Nickel (II) Ion, Int. J. Sci. Eng. Res. 6 (11) (2015) 735-743.

[41] A. Bhowmick, M. Islam, R. Bhowmick, M. Sarkar, A. Shibly, E. Hossain, Synthesis and Structure Determination of Some Schiff Base Metal Complexes with Investigating Antibacterial Activity, Am. J. Chem. 9 (1) (2019) 21-25.

https://doi.org/10.5923/j.chemistry.20190901.03

[42] C. Şenol, Z. Hayvali, H. Dal, T. Hökelek, Syntheses, characterizations and structures of NO donor Schiff base ligands and nickel(II) and copper(II) complexes, J. Mol. Struct. 997 (2011) 53-59. https://doi.org/10.1016/j.molstruc.2011.04.037

[43] M. Sarıül, S.E. Kariper, P. Deveci, H. Atabey, D. Karakaş, M. Kurtoglu, Multiproperties of a new azo-Schiff base and its binuclear copper(II) chelate: Preparation, spectral characterization, electrochemical, potentiometric and modelling studies, J. Mol. Struct. 1149 (2017) 520-529. https://doi.org/10.1016/j.molstruc.2017.08.016

[44] T. Eren, M. Kose, K. Sayin, V. McKee, M. Kurtoglu, A novel azo-aldehyde and its Ni(II) chelate; synthesis, characterization, crystal structure and computational studies of 2-hydroxy5- $\{(\mathrm{E})$-[4-(propan-2- yl) phenyl] diazenyl $\}$ benzaldehyde, J. Mol. Struct. 1065-1066 (2014) 191-198. https://doi.org/10.1016/j.molstruc.2014.02.052 
[45] V. Govindaraj, S. ramanathan, Synthesis, spectral characterisation, electrochemical, and uorescence studies of biologically active novel Schiff base complexes derived from E-4-(2hydroxy-3-Methoxy benzlideneamino)-N-(pyrimidin-2-yl) benzenesulfonamide Valarmathy, Turk. J. Chem. 38 (2014) 521-530. https://doi.org/10.3906/kim-1301-83

[46] S.A. Beyramabadi, B. Esmaeili, A. Gharib, M. Khorsandi-Chenarboo, A. Morsali, M. Khashi, R. Sanavi-Khoshnood, Synthesis, experimental and DFT characterization of the 2((E)-(2-[(E)-2,3-Dihydroxybenzylideneamino]-5-methylphenyl) iminiomethyl)-6-hydroxy phenolate and its Ni(II) and Cu(II) complexes, J. Mol. Struct. 1146 (2017) 620-628. https://doi.org/10.1016/j.molstruc.2017.06.050

[47] Y. Bellal, S. Keraghel, F. Benghanem, L. Toukal, G. Sığırcık, R. Bourzami, A. Ourari, A New Inhibitor for Steel Rebar Corrosion in Concrete: Electrochemical and Theoretical Studies, Int. J. Electrochem. Sci. 13 (2018) 7218-7245. https://doi.org/10.20964/2018.07.91

[48] J. Losada, I. del Peso, L. Beyer, Electrochemical and spectroelectrochemical properties of copper(II) Schiff-base complexes, Inorg. Chim. Acta. 321 (2001) 107-115.

https://doi.org/10.1016/S0020-1693(01)00511-4

[49] A. Fatoni, P.L. Hariani, Hermansyah, A. Lesbani, synthesis and characterization of Schiff base 4,4-diaminodiphenyl ether vanillin possessed of free primary amine, IOP Conf. Series: J. Phys. Conf. Series 1095 (2018) 012002 1-9. https://doi.org/10.1088/1742$\underline{6596 / 1095 / 1 / 01200}$

[50] Md.R. Hasan, M.A. Hossain, Md.A. Salam, M.N. Uddin, Nickel complexes of Schiff bases derived from mono/diketone with anthranilic acid: Synthesis, Characterization and microbial evaluation, J. Taibah. Univ. Sci. 10 (2016) 766-773.

http://dx.doi.org/doi:10.1016/j.jtusci.2015.11.007

[51] Z. Zhou, R.G. Parr, Activation Hardness: New Index for Describing the Orientation of Electrophilic Aromatic Substitution. J. Am. Chem. Soc. 112 (1990) 5720-5724.

https://doi.org/10.1021/ja00171a007

[52] K. Fukui, The Role of Frontier Orbitals in Chemical Reactions (Nobel Lecture) Angew Chemistry International Edition, 21 (1982) 801-809. https://doi.org/10.1002/anie.198208013

[53] S. Kumar, A. Hansda, A. Chandra, A. Kumar, M. Kumar, M. Sithambaresan, S.H. Faizi, V. Kumar, R.P. John, $\mathrm{Co}(\mathrm{II}), \mathrm{Ni}(\mathrm{II}), \mathrm{Cu}(\mathrm{II})$ and $\mathrm{Zn}$ (II) complexes of acenaphthoquinone 3-(4Benzylpiperidyl) thiosemicarbazone: Synthesis, structural, electrochemical and antibacterial Studies, Polyhedron 134 (2017) 11-21. http://dx.doi.org/10.1016/j.poly.2017.05.055

[54] S.W. Hwang, Y. Chen, Synthesis and Electrochemical and Optical Properties of Novel Poly (arylether)s with Isolated Carbazole and p-Quaterphenyl Chromophores, Macromolecules 34 (2001) 2981-2986. https://doi.org/10.1021/ma001855z

[55] S.M. Kuzmin, S.A. Chulovskaya, V.I. Parfenyuk, Mechanism and superoxide scavenging activity of hydroxy substituted tetraphenylporphyrins via coulometric approach, J. Electroanal. Chem. 772 (2016) 80-88. https://doi.org/10.1016/j.jelechem.2016.04.024 
[56] K.M. Schaich, X. Tian, J. Xie, Reprint of Hurdles and pitfalls in measuring antioxidant efficacy: A critical evaluation of ABTS, DPPH, and ORAC assays, J. Funct. Foods. 18 (2015) 782-796. https://doi.org/10.1016/j.jff.2015.05.024

[57] V. Bondet, W. Brand-Williams, C. Berset, Kinetics and Mechanisms of Antioxidant Activity using the DPPH ${ }^{*}$ Free Radical Method, LWT-Food. Sci. Tech. 30 (6) (1997) 609615. https://doi.org/10.1006/fstl.1997.0240

[58] Beena, D. Kumar, D.S. Rawat, Synthesis and antioxidant activity of thymol and carvacrol based Schiff bases, Bioorg. Med. Chem. Lett. 23 (2013) 641-645.

https://doi.org/10.1016/j.bmcl.2012.12.001

[59] H. Kaur, G. Hippargi, G.R. Pophali, A.K. Bansiwal, Treatment methods for removal of pharmaceuticals and personal care products from domestic waste water, Pharmaceuticals and Personal Care Products: Waste Management and Treatment Technology, (2019) 129-150. https://doi.org/10.1016/B978-0-12-816189-0.00006-8

[60] B.J. Finlayson-Pitts, J.N. Pitts, CHAPTER 6 - Rates and Mechanisms of Gas-Phase Reactions in Irradiated Organic-NOx-Air Mixtures, Chemistry of the Upper and Lower Atmosphere (2000) 179-263. https://doi.org/10.1016/B978-012257060-5/50008-3

[61] L. Barros, M.J. Ferreira, B. Queirós, I.C.F.R. Ferreira, P. Baptista, Total phenols, ascorbic acid, $\beta$-carotene and lycopene in Portuguese wild edible mushrooms and their antioxidant activities, Food Chem. 103 (2007) 413-419.

https://doi.org/10.1016/i.foodchem.2006.07.038

[62] M.M. Naidu, B.N. Shyamala, J.P. Naik, G. Sulochanamma, P. Srinivas, Chemical composition and antioxidant activity of the husk and endosperm of fenugreek seeds, LWTFood. Sci. Tech. 44 (2011) 451-456. https://doi.org/10.1016/j.lwt.2010.08.013 
GRAPHICAL ABSTRACT

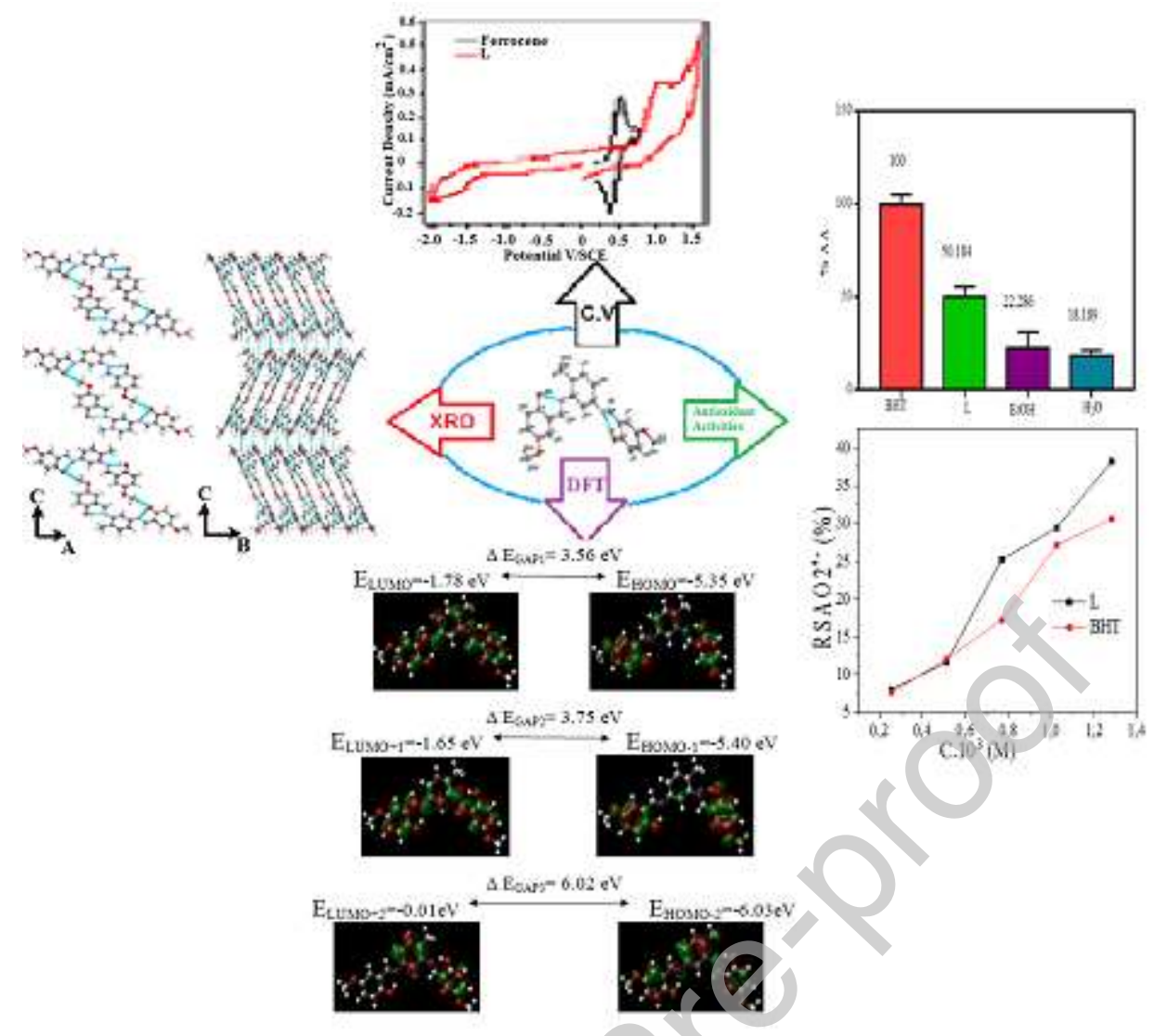

